
(1) $\begin{aligned} & \text { Nordic Council } \\ & \text { of Ministers }\end{aligned}$
.

\title{
Nordic fisheries and aquaculture
}

Socio-economic importance of nitrogen nutrient load in the environment

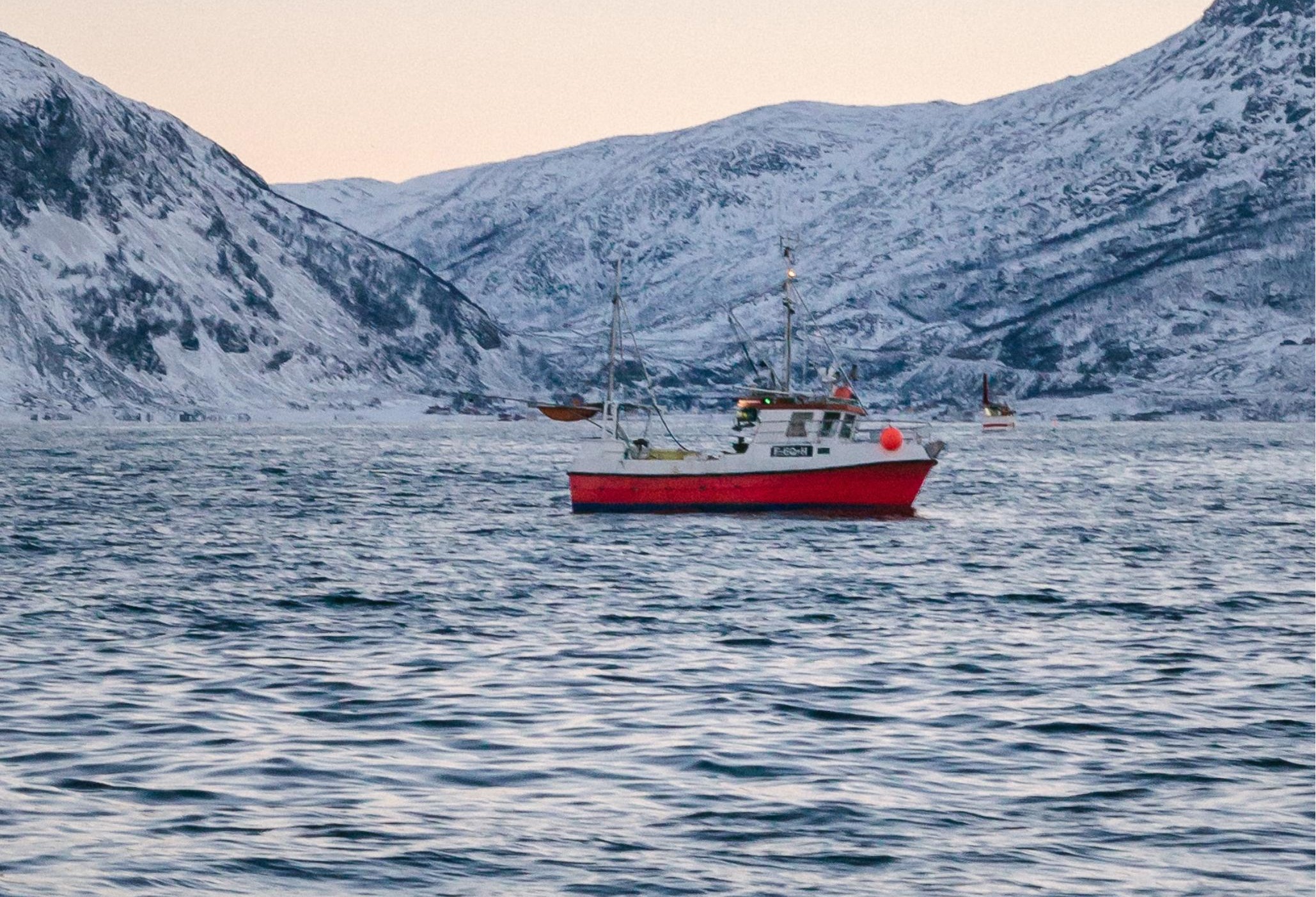





\section{Nordic fisheries and aquaculture}

Socio-economic importance of nitrogen nutrient load in the environment

Max Nielsen, Ayoe Hoff, Rasmus Nielsen, Staffan Waldo, Cecilia Hammerlund, Valerio Bartolino, Frank Asche and Jay Abolofia

TemaNord 2017:504 
Nordic fisheries and aquaculture

Socio-economic importance of nitrogen nutrient load in the environment

Max Nielsen, Ayoe Hoff, Rasmus Nielsen, Staffan Waldo, Cecilia Hammerlund, Valerio Bartolino, Frank Asche and Jay Abolofia

ISBN 978-92-893-4845-4 (PRINT)

ISBN $978-92-893-4846-1$ (PDF)

ISBN 978-92-893-4847-8 (EPUB)

http://dx.doi.org/10.6027/TN2017-504

TemaNord 2017:504

ISSN $0908-6692$

Standard: PDF/UA-1

ISO 14289-1

(c) Nordic Council of Ministers 2017

Layout: NMR

Cover photo: Scanpix

Print: Rosendahls-Schultz Grafisk

Printed in Denmark

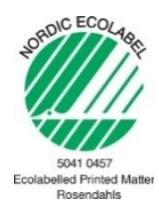

Although the Nordic Council of Ministers funded this publication, the contents do not necessarily reflect its views, policies or recommendations.

\section{Nordic co-operation}

Nordic co-operation is one of the world's most extensive forms of regional collaboration, involving Denmark, Finland, Iceland, Norway, Sweden, the Faroe Islands, Greenland, and Åland.

Nordic co-operation has firm traditions in politics, the economy, and culture. It plays an important role in European and international collaboration, and aims at creating a strong Nordic community in a strong Europe.

Nordic co-operation seeks to safeguard Nordic and regional interests and principles in the global community. Shared Nordic values help the region solidify its position as one of the world's most innovative and competitive. 


\section{Contents}

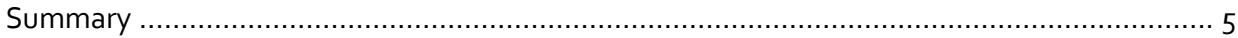

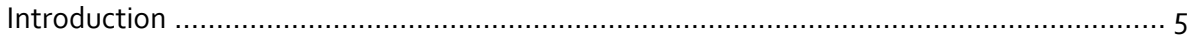

Case I: Fisheries management under nutrient influence: Cod fishery in the

Western part of the Baltic Sea ....................................................................... 5

Case II: Influence of nutrients on growth of salmon at marine fish farms in the

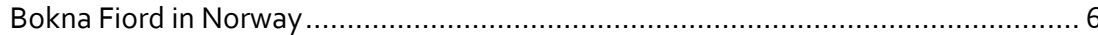

Workshop: Perspectives on importance of nitrogen for Nordic fisheries and aquaculture $\ldots . .7$

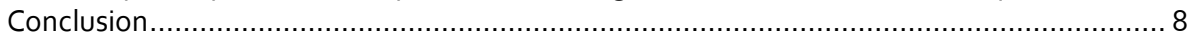

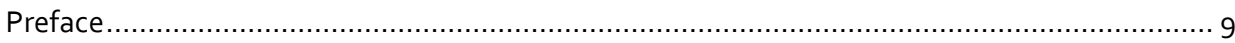

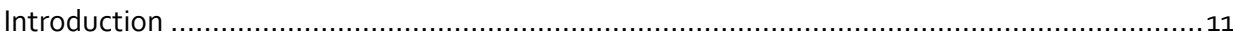

1. Case I: Fisheries management under nutrient influence: Cod fishery in the

Western part of the Baltic Sea.

1.1 Introduction

1.2 Background and purpose

1.3 Nutrients, regulations, and the cod fishery in the Western part of the Baltic Sea.......15

1.4 Model of optimal fisheries management under nitrogen influence .........................18

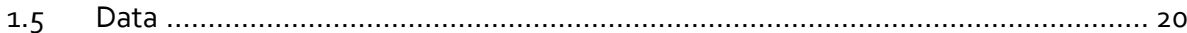

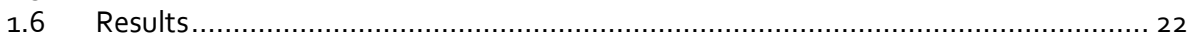

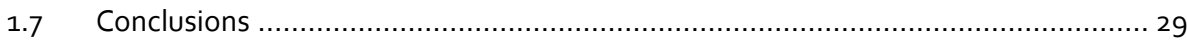

2. Case II: Influence of nutrients on growth of salmon at marine fish farms in the

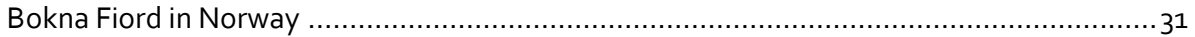

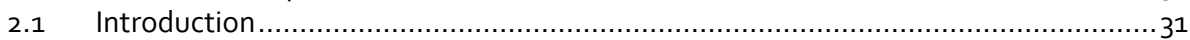

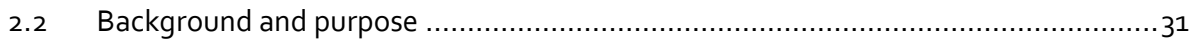

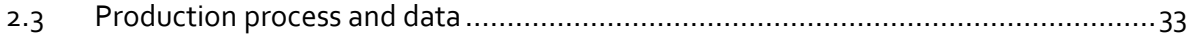

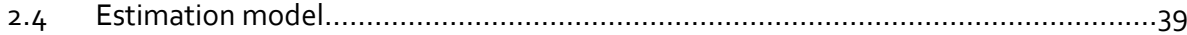

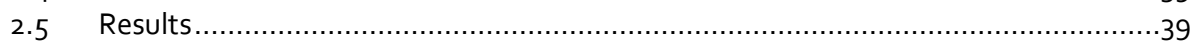

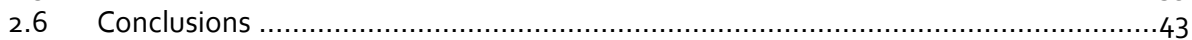

3. Perspectives on importance of nitrogen for Nordic fisheries and aquaculture ................. 45

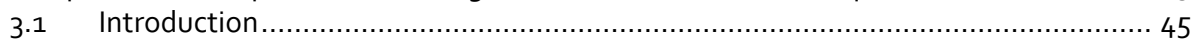

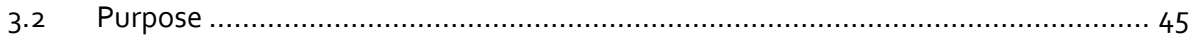

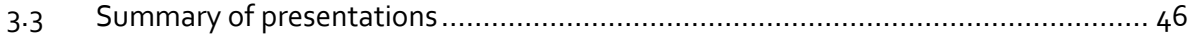

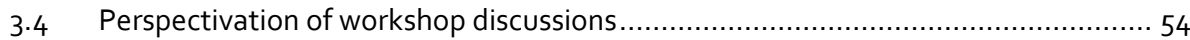

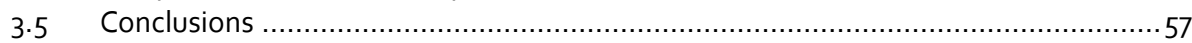

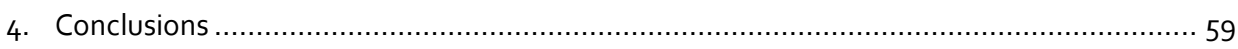

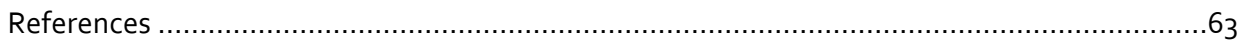




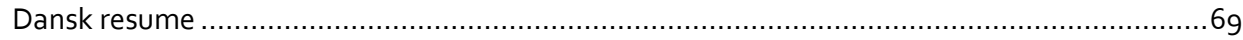

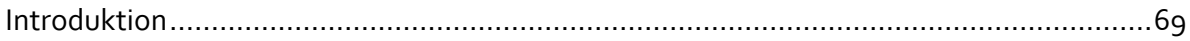

Case studie I: Forvaltning af fiskeri under påvirkning af næringsstoffer -

Torskefiskeri i den vestlige del af Østersøen....................................................69

Case studie II: Næringsstoffers påvirkning af vækstraten for laks i havbrug i

Bokna Fjorden i Norge ........................................................................... 70

Workshop: Perspektiver om betydningen af kvælstof for nordisk fiskeri og akvakultur....... 71

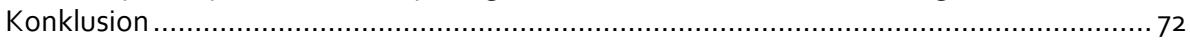

Appendix A. Description of the bio-economic model of fisheries applied in case I.................. 73

Appendix B. Description of the estimation model of aquaculture applied in case II ................. 77

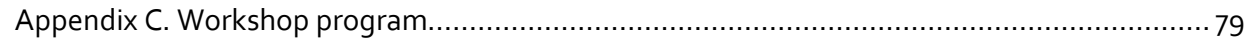

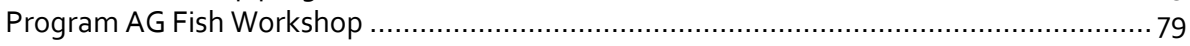

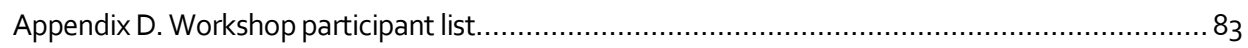




\title{
Summary
}

\author{
Introduction
}

This report contributes to the understanding of how the the socio-economic contribution of Nordic fisheries and aquaculture are affected by the environment and environmental management, with a focus on nutrients and nitrogen. The report contains two case studies of how the socio-economic contribution of Danish and Swedish cod fisheries in the Western part of the Baltic Sea are affected by the concentration of nitrogen in the sea, and on how the growth rates of salmon in aquaculture in the Bokna Fiord are affected by nitrogen concentration. Furthermore, a Nordic workshop has been held with the title: Fisheries, aquaculture and the marine environment: Environmental challenges and regulation, with focus on nitrogen. The finding of the case studies were presented at the workshop, together with presentations made by invited speakers on the role of nutrients and their management for Nordic fisheries and aquaculture. The discussion at the workshop is summarized in this report.

\section{Case I: Fisheries management under nutrient influence: Cod fishery in the Western part of the Baltic Sea}

The purpose of this case was to analyze the consequences for the socio-economic contribution of the Danish and Swedish fishing fleet of reducing the nitrogen concentration and changing fisheries policy in the Western part of the Baltic Sea. The basis for the analysis was that it has earlier been shown that the correlation between the concentration of nitrogen and the size of the cod stock was positive in the period from 1940 to 1980. During this period, the concentration of nutrients had a positive effect on the size of the cod stock. Since the 1980 s, nitrogen has from an environmental perspective been regarded as problematic. At the same time environmental policies has introduced limits on discharges of nutrients and nitrogen in most countries around the Baltic Sea. In recent years there has been a fall in discharges of nitrogen and phosphor into the Baltic Sea, whereas the measured concentration of nutrients in the water is not reduced accordingly. Algal biomass has been declining and the prevalence of seabed areas with oxygen deficit is increasing. The analysis used a bio-economic model of fisheries in 
which the socio-economic optimal fleet size for cod fisheries with passive gears in the Western part of the Baltic Sea is identified. This model is extended to take the effect of nitrogen concentration into account, i.e. identifies a combined optimal fleet size and nitrogen concentration leading to socio-economic optimum. The fundamental relationship included in the model is that an increase in the nitrogen concentration, all other things being equal, leads to larger cod stock up to a certain point. After this point, higher nitrogen concentration will reduce the cod stock, due to eutrophication. Despite the fact that the nitrogen concentration currently observed in the Western part of the Baltic Sea is higher than corresponding to the optimal nitrogen concentration it is estimated that we are close to the optimal concentration today. The results indicated that the effect of changes in nitrogen concentrations on the socio-economic contribution of fishery activities in the Western part of the Baltic Sea is small. There are, however, significant socio-economic benefits of reducing the fleet size. The socio-economic contribution of the cod fisheries in the Western part of the Baltic Sea can be significantly improved by a fleet reduction, but nitrogen is not of large importance for the socio-economic contribution of the fishery.

\section{Case II: Influence of nutrients on growth of salmon at marine fish farms in the Bokna Fiord in Norway}

The purpose was to estimate the interaction between nitrogen concentrations in the sea and the growth rate of salmon, thereby revealing how the marine farms are affected by nutrient discharges, no matter whether they originate from land-based sources or from other marine farms. Detailed regression analyses were performed without being able to identify any interaction between nutrient concentrations in the water and growth rates of salmon. The reason for this result remain a matter of speculation, but it is believed that it is related to the fact that less than $3 \%$ of the nutrient load in Norway originates from human activities, as compared to $82 \%$ in Denmark. Thus, even though a political purpose in Norway is to reduce nutrient discharges, the conclusion is that high nutrient concentrations may not form a large problem for Norwegian salmon aquaculture. In warm summers, however, oxygen depletion is occasionally a local problem. 


\section{Workshop: Perspectives on importance of nitrogen for Nordic fisheries and aquaculture}

The workshop Fisheries, aquaculture and the marine environment: Environmental challenges and regulation, with focus on nitrogen was held in Copenhagen in June 2015. The focus was on the importance of nutrients for the socio-economy and sustainable growth of Nordic fisheries and aquaculture. Different approaches to the management of the marine environment were discussed, including ecosystem management, management based on natural capital and economic valuation of ecosystem services. The potential problems, that require management to be handled properly from a socioeconomic perspective, discussed were: 1 ) the discharge of nitrogen and phosphor from aquaculture, which causes negative environmental externalities on the aquatic environment and other fish farms, 2) nitrogen and phosphor uptake in farmed mussels and seaweed that, via the cleaning effect, has a positive environmental effect, 3) the effect of nutrient concentrations in marine areas on the productivity of fish stocks and the fishery economy, an effect that is positive at low concentrations, due to an increased feed base for the fish, but negative at high concentrations because of eutrophication, and 4) removal of nitrogen and phosphor in wild-caught fish, which evokes a positive environmental effect. The discussion pointed to the fact that despite the fact that fisheries are affected by changing nutrient concentrations, a reduction in nutrient concentration is not expected to cause a considerable impact on the socio-economic contribution of the cod fishery. Therefore, the socio-economic contribution of fisheries can be improved only through the use of fishery management instruments such as individual transferable quotas in order to "avoid that there are too many fishermen to catch too few fish". For aquaculture, nitrogen does not appear to pose a major challenge for the ecosystems in Norway. But the situation is quite different in the Baltic Sea, where the main barrier to sustainable growth of aquaculture is considered to be the current environmental management of nutrients. The opportunities for sustainable growth of aquaculture in the Baltic region was discussed and the following options were mentioned: 1) more efficient nitrogen management in the form of individually tradable nitrogen quotas, 2) purification of water by removing nutrients through fishing, 3) purification of water by nutrient removal in mussel and seaweed farming (including compensation farming), and 4) development of environmentally friendly technologies for aquaculture and closed and semi-closed (recirculation) systems, where fish production is decoupled from the environment. 


\section{Conclusion}

This report contributes with understanding of the impact of nitrogen on the socio-economic contribution of Nordic fisheries and aquaculture. It was found that nitrogen is of importance in the Baltic Sea, but there are no indications of considerable problems elsewhere in the Nordic area. The interaction between fisheries and aquaculture on the one hand, and nitrogen on the other, is primarily of interest in Denmark, Finland and Sweden. In Finland, however, phosphor is more important than nitrogen. Nitrogen management has a significant impact on aquaculture in the Baltic Sea and is considered to be a limiting factor for sustainable growth. If sustainable growth in Danish, Finnish and Swedish aquaculture has to be achieved, the management of nitrogen must necessarily be handled. Fisheries and aquaculture have the opportunity to further develop cleaning measures in the form of removal of nutrients from catching fish and by breeding mussels and seaweed. The mussel and seaweed production already exist today in several places in the Nordic region and further development of them may be of common Nordic interest. Cleaning measures have positive environmental effect and their development can be considered for inclusion in the environmental policy. For example, by introducing a payment scheme where agriculture farmers pay mussel farmers and fishermen to clean up after them. The report did not assess the economy of this.

Based on the two case studies and input at the workshop, conclusions of relevance for the policy issues of today was summarized to that:

- There are no indications that the socio-economic contribution of Danish and Swedish cod fisheries in the Western part of the Baltic Sea will be considerably affected by changed nitrogen concentration in the Baltic Sea.

- There are no indications that the profitability of Norwegian salmon farming is considerably affected by nutrients.

- The socio-economic contribution of fishing in the Western part of the Baltic Sea is expected to improve when the structural adjustment following individual transferable quotas gradually continues in Denmark and if introduced in Sweden.

- Management of nitrogen is the crucial barrier for sustainable growth of aquaculture in the Baltic Sea.

- Nutrients and nitrogen is of large importance to aquaculture in the Baltic Sea, but contrary to this the studies presented in this report indicate that they are of little importance to fisheries in the Baltic Sea and that they are of very limited importance for fisheries and aquaculture in the remaining Nordic region. 


\section{Preface}

The activities of fisheries and aquaculture are undertaken as part of marine ecosystems and the sectors depend on and affect these ecosystems, in good and bad ways. Simultaneously, one of the most important factors affecting the health of marine ecosystems is the concentration of nutrients and in particular nitrogen in the water. The reason is that eutrophication with unnaturally high concentrations of nitrogen might be a result of continuous high nitrogen discharges.

Fisheries are affected by nitrogen concentrations. At low levels, nitrogen support life in the sea by increasing the feed base for commercially important fish stocks. At high levels, however, eutrophication occurs, inducing oxygen depletion and reduce the healthiness of benthic ecosystems. This in turn affects fish stock sizes, and therefore catches and the socio-economic contribution of commercial important species are affected.

The economy of aquaculture can also be affected by nitrogen concentrations. Partly due to reduced growth of fish when reared in over-fertilized waters, partly through adjustment costs to meet possible requirements for the reduction of nitrogen discharge.

In this report, the Socio-economic importance of nitrogen nutrient load in the environment for Nordic fisheries and aquaculture is analyzed through two case studies on the West Baltic cod fishery of Denmark and Sweden and on salmon farming in the Bokna Fiord in Rogaland, Norway. The results form the basis for a broad discussion of the Socio-economic importance of nitrogen nutrient load in the environment for Nordic fisheries and aquaculture and for design of management of fisheries and aquaculture as well as nitrogen. The aim of the report is to provide knowledge on how nitrogen concentrations and discharges can improve the basis for management of Nordic fisheries and aquaculture. The intended readers are civil servants, politicians, researchers and stakeholders with an interest in fisheries and aquaculture.

This report is part of the project Potential for green growth in Nordic fisheries and aquaculture through reduced discharges of nitrogen, funded by the Nordic Council of Ministers. It consists of two case studies and a discussion of the broader perspectives. The first case study, Fisheries management under nutrient influence: Cod fishery in the Western part of the Baltic Sea, is presented in chapter 2. It is written by Max Nielsen, Ayoe Hoff and Rasmus Nielsen, Institute of Food and Resource Economics, University 
of Copenhagen, by Cecilia Hammarlund and Staffan Waldo, AgriFood Economics Centre, Swedish University of Agricultural Sciences and Lund University and by Valerio Bartolino, Department of Aquatic Resources, Swedish University of Agricultural Sciences. The second case study, Influence of nutrients on the growth of salmon at marine fish farms in the Bokna Fiord, is presented in chapter 3 . It is written by Frank Asche and Jay Abolofia, University of Stavanger. The discussion of the broader perspectives on importance of nitrogen for Nordic fisheries and aquaculture in chapter 4 is a summary on the presentations made at the Nordic Workshop Fisheries, aquaculture and the marine environment: Environmental challenges and regulation, with focus on nitrogen, held in Copenhagen in June 2015. The views expressed in the report are solely the view of the authors.

The authors acknowledge input from presenters and participants at the workshop and hope that the report will contribute with knowledge on the role of nitrogen in the future management of fisheries and aquaculture. 


\section{Introduction}

The purpose of this report is to improve knowledge on the socio-economic importance of nitrogen for fisheries and aquaculture The purpose is further to improve knowledge on how to design fisheries and aquaculture management to take nitrogen discharges into account, and to identify the role of fisheries and aquaculture in the environmental management. Finally, alternatives and supplements to management such as mussel farming and removing nutrients through fish caught are discussed. Questions addressed are: Can the socio-economic contribution of fisheries increase if nitrogen discharges are reduced? How much? Or would the socio-economic contribution of fisheries to society fall? How is the growth rate of salmon at marine farms affected by nitrogen concentration in the water? How does that affect the economy of the marine farms? Does the effect depend on management of fisheries and aquaculture?

The socio-economic contribution is measured as the sectors contribution to the Gross Domestic Product (GDP) in excess of what could have been achieved if production factors have been used in other sectors. The issue of the socio-economic importance of nitrogen for the sectors is analyzed in two case studies, followed by a discussion of the broader perspectives of the importance of nitrogen for Nordic fisheries and aquaculture. The first case study covers the Danisn and Swedish cod fishery in the Western part of the Baltic Sea. This case study is performed using a bio-economic model of fisheries, extended with a biological growth function that depends not only on fishing effort but also on nitrogen concentrations in the sea. The second case study analyzes the effect of nitrogen for the growth of salmon in marine aquaculture in the Bokna Fiord in Rogaland, Norway. This analysis is founded in production economics applying regression analysis.

The first hypothesis is that reductions in nitrogen concentrations can improve the socio-economic contribution of the cod fishery in the Western part of the Baltic Sea. It is well-documented that the nitrogen concentration in this area is high, and reducing this may thus be expected to lead to increased contribution from the cod fishery in the area that already have considerable socio-economic importance. The second hypothesis is that this potential of improved economy is less than the growth potential appearing from a possible shift from traditional to economically optimal management, i.e. to Individually Transferable fishing rights.

In Norwegian fjords, the nitrogen concentration is less documented, as well as consensus on the importance for Norwegian salmon farming does not exist scientifically. 
KLIF (2010) finds that salmon farming is the largest human source of nutrient pollution along the Norwegian coast, but the Norwegian Institute of Marine Research (2011) indicates that these are small compared to natural sources and do not have any significant impact. Asche and Bjørndal (2011) find that there has been evidence of eutrophication at some locations and that hypoxia is an increasing challenge. On this basis, the third hypothesis is that the growth rate for salmon, and through this the economics of salmon farming, is negatively affected.

At the Nordic workshop Fisheries, aquaculture and the marine environment: Environmental challenges and regulation, with focus on nitrogen, held in Copenhagen in June 2015 , the perspectives of the Socio-economic importance of nitrogen nutrient load in the environment for Nordic fisheries and aquaculture were discussed. Several issues (market failures) related to the efficiency of management of fisheries and aquaculture and the interaction of these with nitrogen in the marine environment were discussed: 1) Discharges of nitrogen and phosphor from fish farms inducing negative environmental effects and affects the growth rates in nearby fish farms, 2) Nitrogen and phosphor uptake in farmed mussels and seaweed inducing positive environmental (cleaning) effect, 3) Effects of nutrient concentrations in marine areas on fish stock productivity and the socio-economics of fisheries, which are positive at small concentrations with an increased feed basis, but negative at high concentrations with eutrophication, 4) Nitrogen and phosphor removal in fish caught by fishing, inducing a positive environmental effect, and 5) The effect of bottom trawling on visibility in waters, where bottom trawling might amplify and spread the effect of nutrients depositions at the sea floor and thereby potentially induce negative environmental effects.

The report is expected to contribute to the understanding of the importance of management of nitrogen for the socio-economic contribution of fisheries and aquaculture, including whether and to what extent it is from a socio-economic perspective economically advantageous to include fisheries and aquaculture as an integrated part of the management of the water environment. Hence, the report creates new knowledge contributing to the extensive agenda on the management of marine areas that includes integrated coastal zone and marine management, ecosystem management and green growth. This knowledge is expected to become more and more important in the future.

The report is organized as follows: Chapter 2 presents the first case study on fisheries management under nutrient influence focus at the cod fishery in the Western part of the Baltic Sea. In chapter 3 , the second case study on nutrient influence on growth of salmon at marine fish farms in the Bokna Fjord is presented. Chapter 4 reports on the workshop discussion of broader perspectives of importance of nitrogen for Nordic fisheries and aquaculture. Chapter 5 concludes the report. 


\section{Case I: Fisheries management under nutrient influence: Cod fishery in the Western part of the Baltic Sea}

\subsection{Introduction}

The purpose of this chapter is to identify economic optimal management of fisheries under the influence of nutrients, focusing on the Swedish and Danish cod fisheries with passive gears in the Western part of the Baltic Sea. The Western part of the Baltic Sea is chosen, since cod fishing is extensive in this area and since it forms part of a semi-closed marine environment that has been subject to discharges of nitrogen for many years. The chapter extends existing bio-economic models of fisheries to analyze not only the effect of fishing, but also the effect of nitrogen concentration on the West Baltic cod stock. This case study is performed by Max Nielsen, Ayoe Hoff, and Rasmus Nielsen, Institute of Food and Resource Economics, University of Copenhagen, Denmark, by Cecilia Hammarlund and Staffan Waldo, AgriFood Economics Centre, Swedish University of Agricultural Sciences and Lund University and by Valerio Bartolino, Department of Aquatic Resources, Swedish University of Agricultural Sciences.

\subsection{Background and purpose}

When tightening environmental regulations to improve the marine environment of the Baltic Sea (Helcom 2007, 2014; European Commission 1991, 2000, 2008), increased attention should also be paid to the economic activity of fishing and how it must be managed to maximize its socio-economic contribution. The purpose of this study is to develop a model for identifying welfare-optimal management of fisheries under the influence of nutrients. We measure the socio-economic contribution of fisheries, corresponding to the extra contribution to GDP of applying production factors in fisheries 
compared to other sectors. The model is applied to the Swedish and Danish cod fisheries with passive gears in the Western part of the Baltic Sea. Furthermore, the influence of reduced nitrogen concentration, following strict environmental regulations, on optimal fishery management is examined. The welfare optimum includes both the resource rent and the producer surplus, and therefore the analysis adopts a welfare economic perspective. The approach is based on a comparative-static bio-economic model, extended with a biological growth function that depends not only on fishing effort, but also on nutrient concentrations in the sea. It takes into account that more nitrogen leads to more feed, which potentially leads to growth in cod stocks to a level where eutrophication reduces the life of benthic ecosystems and thereby limits the cod stock.

Given the focus on improving the environmental status of the Baltic Sea through environmental policy (Helcom 2007; 2014), taking the effect of nitrogen concentrations on the West Baltic cod stock into account might change the optimal fisheries policy from a biological point of view. If the nitrogen stock is higher than the optimal concentration, a reduction could improve the growth conditions for the Baltic cod stock. Conversely, if the nitrogen content is below the optimal level, a further reduction could limit potential growth of the stock. This study finds that the effect of taking nutrient concentrations into account in fisheries management policies is limited, even though, the Baltic Sea have one of the world's highest concentration of nutrient (Pedersen et al., 2006; Helcom 2007). Improved welfare contribution of fisheries thus remain based on wellknown instruments, such as individual transferable quotas.

Knowledge on the effects of nutrients on the economics of fishing is important, since most fisheries are performed in waters within national extended economic zones, where nutrients from land-based sources are present in large concentrations. Furthermore such knowledge can show whether fertilization of the sea is economically advantageous, by increasing the exploitable marine resources. As opposed to field fertilization in agriculture, where farmers control the amount of fertilizer on their property to ensure optimal growth and output, fertilization of the sea by nutrients is an undesired externality, and carries a risk of harming the marine environment. Hence, the control option is small and the risk of over-fertilization large (McCann and Yodzis, 1994).

A number of studies have incorporated environmental externalities into bio-economic models of fisheries (Barbier and Strand, 1998; Simonit and Perrings, 2005; Foley et al., 2009; Udumyan et al., 2010; Foley et al., 2012; Nguyen et al., 2013; Smith et al., 2014; Nguyen et al., 2015). Barbier and Strand (1998) study the effect of changes in mangrove areas on the carrying capacity of shrimp stocks in Mexico, while Simonit and Perring (2005) look at effects of eutrophication on growth of fish in Lake Victoria. Foley et al. (2012) identify the effect of habitat quality on carrying capacity and growth rates in a theoretical set-up. All depart from the Gordon-Schaefer model (Gordon, 1954; Schaefer, 
1957). Nguyen (2013) and Nguyen et al. (2015) maximize the net present value of profits of the East Baltic cod fishery under the influence of eutrophication by applying a dynamic empirical model. They show that the marginal damage to the fish stock is small compared with the marginal abatement cost of land-based polluters. In the present study, we determine the welfare optimum in a comparative static model of fish stocks with growth rate and carrying capacity being additionally dependent on nitrogen, in an analysis which identifies and builds on the level of nitrogen that is optimal in relation to maximizing the size of the West Baltic cod stock.

The remainder of the chapter is organized as follows: In section three, nutrient concentrations, regulations, and the cod fishery of the Western part of the Baltic Sea are described. In section four, a model for optimal management of fisheries under the influence of nutrients is developed. Section five and six present data and results, and the final section present some conclusions from this fishery case study.

\subsection{Nutrients, regulations, and the cod fishery in the Western part of the Baltic Sea}

In the 1990s, increasing concerns about the negative effects of eutrophication of European waters resulted in two EU directives. Council Directive 91/676/EC focused on protection of waters against emissions of nitrates from agricultural sources and required all member states to identify vulnerable zones, establish action plans for limiting nitrogen losses from agriculture, and promote good agricultural practices (EC, 1991). Around ten years later, the EU Water Framework Directive (Directive 2000/60/EC) was established, taking a wider perspective on the environmental problems in the field of water policy. This directive states that all member states must introduce regulations to improve the quality of surface waters, groundwater, and protected areas (EC, 2000). For the Baltic Sea countries, limiting eutrophication in the Baltic Sea has become a major issue in order to meet the objectives of the directive.

More recently, in 2008, a marine strategy framework (Directive 2008/56/EC of the European Parliament and of the Council of 17 June 2008) for community action in the field of marine environmental policy was issued. Its aim is for all sea areas of the EU to achieve "good environmental status" by the end of 2020. It requires all member states to define the environmental status in their seas and establish action plans for solving environmental problems (EC, 2008).

In addition to the EU directives, HELCOM (Baltic Marine Environment Protection Commission - Helsinki Commission) is working through intergovernmental cooperation to protect the marine environment of the Baltic Sea. In 2007, HELCOM established 
the Baltic Sea Action Plan with the objective of achieving "good environmental status" for the Baltic by 2021. The measures in the action plan will be implemented in 2016. The plan also establishes the level of reduction in nitrogen and phosphor emissions that is required from each country. In total, HELCOM requires that emissions of nitrogen and phosphor be reduced by 133,000 and 15,000 tons, respectively, by 2016 (Helcom, 2007).

Although the framework of the legislation is established in the EU directives and the Baltic Sea Action Plan, it is up to individual states to implement the regulations to meet the objectives. In Denmark, environmental water action plans have been in place since 1985 , with the objective of reducing losses of nitrogen and phosphor to Danish waters. For example, the objectives in the plan established in 1987 were to reduce losses of nitrogen by $50 \%$ and losses of phosphor by $80 \%$. When these objectives were met, in 2004, new objectives were established (Dalgaard et al., 2014). It has proven to be relatively easy to reduce phosphor losses to Danish waters, whereas reducing losses of nitrogen has been somewhat more difficult, since its sources are more diffuse. There has recently been increased focus on reducing nitrogen losses from Danish agriculture. For example, in the third environmental water action plan established in 2004, protection zones around lakes and rivers are required (Dalgaard et al., 2014).

In Sweden, 15 national environmental quality objectives were established in 1999 and one of these, "No eutrophication", is related to loss of nutrients to waters. The overall objective is for substances causing eutrophication in soil and waters to be reduced to a level where they do not affect health, biological diversity, or the use of soil and waters. This objective is partitioned into underlying objectives specifying how emissions of nitrogen, phosphor, ammonia, and nitrogen oxide should decrease (Swedish Environmental Protection Agency, 2013).

Evidence from a large number of coastal and semi-enclosed systems shows that increased nutrient loads and organic enrichment generally enhance overall fish biomass production (Nixon and Buckley, 2002; Nagai, 2003; Oczkowski and Nixon, 2008). A positive relationship between nutrient enrichment and fisheries yields is often observed over large spatial scales and considering the entire harvested biomass spanning across different trophic levels (Breitburg et al., 2009). However, oxygen deficiency has negative implications for a number of fish and macro-invertebrate species, affecting their physiology (Claireaux and Dutil, 1992) and behavior (Baden et al., 1990), and fragmenting and reducing essential habitats necessary for their reproduction and feeding (Breitburg, 2002). Eggs and early life stages are particularly vulnerable to oxygen deficiency because of their low ability to avoid adverse conditions and because of their generally higher oxygen requirements (Vallin and Nissling, 2000). Moreover, the reproductive habitat of cod has shrunk due to oxygen deficiency, with negative consequences on its recruitment (Vallin and Nissling, 2000). Temporary, moderately hypoxic conditions 
may increase predation rates of benthivorous species (Neuenfeldt et al., 2009), but experimental tests on juvenile cod have shown that prolonged exposure compromises physiological functions (Claireaux and Dutil, 1992) and has negative effects on predation efficiency (Tallqvist et al., 1999).

The Western part of the Baltic Sea consists of the Arkona Sea (west of the island of Bornholm), the Belt Sea, and the Sound (ICES area 22-24). There are two separate cod stocks in the Baltic Sea (east and west stocks), of which the western is the smaller stock. Spawning occurs in spring, in the Bornholm Basin in the Eastern part of the Baltic Sea and in deeper parts of the Sound, the Belt Sea, and the Arkona Basin in the Western part of the Baltic Sea (ICES, 2015). The size of the eastern stock was reported as unknown in 2015 (Eero et al., 2015). The abundance of juvenile cod is high, whereas the abundance of larger cod is low, but the reasons for this stock composition are not entirely clear (Eero et al., 2015). In 2010, the size of the western stock was 25,600 (metric) tons (ICES, 2012), with the size corresponding to Maximum Sustainable Yield (MSY) estimated to be 23,000 tons. The fishing pressure for this stock is estimated to be too high to ensure optimal use in the long term (ICES, 2012).

Fishing for cod in the Western part of the Baltic Sea is dominated by Danish, German, and Swedish vessels, and the main gears are gillnets and trawls. In 2013, a total of 13,000 tons of cod were caught in the area, of which Danish vessels caught 7,100 tons, German vessels 3,200 tons, and Swedish vessels 1,700 tons (ICES, 2015). The volume of landings has varied over time and was especially small in the late 1980 and early 19905 . In the mid-1990s, catches reached another peak but since then they have decreased and are currently at the lowest level since the mid-1970s.

The Danish cod fishery in the Western part of the Baltic Sea is performed by vessels using both passive and active gears (gillnet and trawl, respectively). Some of these vessels mainly fish in the Baltic Sea, whereas others only fish for cod seasonally in the Baltic Sea. Since 2007, all Danish vessels are regulated under an individual transferable quota scheme, which has brought about a reduction in the Danish fleet of more than $50 \%$ since 2000 .

The Swedish cod fishery in the area uses either trawl or passive gears (gillnet and long-line). Trawlers are regulated by a system with non-transferable individual quotas, but vessels using passive gear are exempted from this system. Instead, part of the total Swedish cod quota is allocated to catches with passive gear, the so-called "coastal quota". Fishing under this quota is free as long as the vessel has a permit for fishing cod in the Baltic. As in the Danish case, the Swedish fleet has decreased during the last decade; from 1997 to 2011 the reduction was $63 \%$. 


\subsection{Model of optimal fisheries management under nitrogen influence}

Optimal fisheries management, as defined from an economic point of view, is determined in the model by maximizing the welfare contribution of a fishery exploiting a fish stock under the influence of nutrients, where the welfare contribution is defined as a net surplus valued at the opportunity cost of production factors. It consists of resource rent and producer surplus from harvesting. Resource rent is the sustained economic return a society can achieve from owning a fish stock, measured as the net surplus that, at a given point in time, remains for the remuneration of capital and labor above the rate achieved in other businesses. Economic theory suggests that resource rent in open access fisheries has a tendency to dissipate and that fisheries operate at a level at which profits correspond to profits that could be earned in other activities (Copes, 1972). Producer surplus, also known as infra-marginal rent, is generated due, e.g., to the fixed cost and heterogeneity of capital and labor (Flaaten, Heen, and Salvanes, 1995). Producer surplus is the sum of the differences between the price received for a good and the price at which individual firms are willing to sell the good. The price at which firms are willing to sell a good is determined by production costs, with remuneration of capital and labor in their opportunity costs.

Optimal fisheries management is identified in the model as the level of fishing effort and the level of nutrients that maximize the welfare contribution, measured as the sum of resource rent and producer surplus. Optimal effort and nutrient levels in this context are determined using a simple comparative static model of one fleet catching one species, where the growth of the fish stock is a function of the nutrient concentration. Fishing effort determines catch, which is thus also affected by nutrients in the long run through the growth rate.

We assume a Schaefer production function and that the growth rate depends on the level of nutrient concentration as well as on fish stock, since the feed base for the fish stock increases with nutrients up to a level above which eutrophication appears and counterbalances the increase, the reason being a reduced feed base and, therefore, a reduced fish stock. Thus in the model MSY is determined both by an optimal level of effort and an optimal level of nutrient concentration. Assuming equilibrium initially together with constant prices, we have that total revenue is equal to the price multiplied by the long run sustainable harvest quantity. The properties of the total revenue of the sustainable yield function, are shown in Figure 1 in relation to fishing effort together with total costs ( $T C$, in panel a) and nutrients (panel b). 

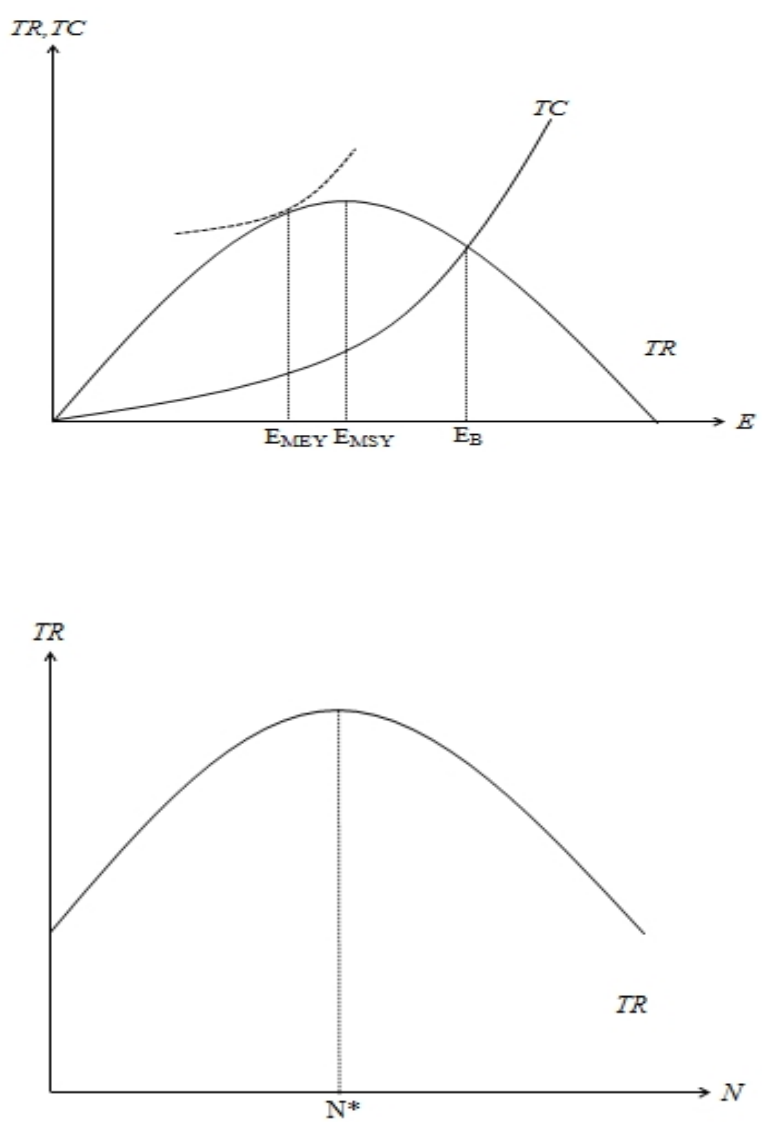

Note: a. Bio-economic model of fisheries with unchanged nitrogen concentraton in the sea.

b. Total revenue dependency of nitrogen concentration in the sea with unchanged fishing effort.

Panel a presents the basics of fisheries economics for a constant level of nitrogen $\mathrm{N}=\overline{\mathrm{N}}$, i.e., total revenue increasing with the sustainable yield until MSY is reached and decreasing afterwards, total cost increasing globally in fishing effort, and the bionomic equilibrium at $\mathrm{E}_{\mathrm{B}}$, with Maximum Economic Yield (MEY) corresponding to the maximum welfare, where marginal revenue equals marginal opportunity costs (Gordon-Schaefer model). Panel $b$ shows total revenue also at the constant price of fish and for a constant level of fishing effort. Without nutrients in the sea fish have no feed and stock and harvest is zero, 
although natural non-human supplies of nitrogen will always ensure a certain level of the stock. Hence, $N *$ is the optimal nutrient level for a certain fishing effort that ensures the maximum steady-state stock and the maximum steady-state harvest.

A policy maximizing the welfare contribution of fisheries is found where fishing effort is $E_{M E Y}$ and where nitrogen is at $N^{*}$. An alternative policy that focuses on environmental conservation may reduce nitrogen relative to $N^{*}$ and thereby lead to a sub-optimal level of fishing effort.

\subsection{Data}

Data for Swedish and Danish cod fisheries in the Western part of the Baltic Sea are taken from national fisheries authorities. The focus is on vessels using passive gear, since most vessels using active gear are mainly fishing in the Eastern part of the Baltic Sea. The Swedish segment included in this study is demersal vessels using passive gears with a length of 10-12 meters. These vessels catch $30 \%$ of their catch in the Western part of the Baltic Sea. The Danish segment includes vessels using passive gears that have more than $50 \%$ of their turnover from the cod fishery in the Baltic Sea. Most of these vessels are less than 12 meters in length, although a few are up to 15 meters. The Danish vessels catch approximately $38 \%$ of their catches in the Western part of the Baltic Sea. Table 1 presents economic data for the two segments separately and the combined total for 2010 .

Table 1: Economic data, 2010

Swedish vessels Danish vessels Total

Share of cod in Western part of the Baltic Sea of total catch value (\%)

$30 \quad 38 a \quad 35$

Number of vessels

$55 \quad 26$

Number of full-time employees

Total catch value, EUR million

$36 \quad 26$

Costs, EUR million

$\begin{array}{lll}2.3 & 3.2 & 5.5\end{array}$

Net profit, EUR million

$\begin{array}{lll}2.5 & 2.3 & 4.8\end{array}$

$\begin{array}{lll}-0.2 & 0.8 & 0.6\end{array}$

Note: $\quad 38 \%$ of turnover of all Danish vessels originates from the Western part of the Baltic Sea. This number is used as a proxy for the amount of cod in the Western part of the Baltic Sea for each segment.

The value of cod catches is larger for the Danish segment than for the Swedish, despite the number of vessels being larger for Sweden. There are 55 Swedish vessels and 26 
Danish, with 36 and 26 full-time employees, respectively. Owing to its higher revenues the Danish segment is profitable, whereas the Swedish is making a loss.

As we are calculating the contribution to welfare of the fisheries, we need information about the opportunity costs of labor and capital. The opportunity cost of capital is the interest that could have been earned by investing the fishing capital elsewhere in the economy. In calculations, we assume that the interest rate is that of 10year bonds from the Swedish central bank, which was 2.9\% in 2010 (Swedish Central Bank, 2015). Due to well-integrated capital markets, this is assumed to be equal for Danish and Swedish companies. The opportunity cost of labor in Sweden is assumed to be the wage of a packager or factory worker, which was EUR 41,184 per full-time equivalent in 2010 (including social security payments). In Denmark, the opportunity cost of labor is assumed to be EUR 48,322 per full-time equivalent in 2010. This corresponds to a weighted average of EUR 44,177 . The labor markets are assumed not to be fully integrated.

The reported labor costs for the Swedish segment are exceptionally small (EUR 0.2 million compared with an opportunity cost of EUR 1.5 million).

Table 2: Salary costs and opportunity costs of labor (thousand EUR)

\begin{tabular}{lccc} 
& Swedish vessels & Danish vessels & Total \\
Salary per full-time employees & 5,293 & 13,079 & 8,558 \\
Opportunity cost per full-time employee & 41,184 & 48,322 & 44,177 \\
\hline
\end{tabular}

To estimate the optimum level of nitrogen for the reproduction of the cod stock, we use a time series of the nitrogen level in the Western part of the Baltic Sea. The nitrogen level is measured at different depths of the sea and has been reported by Helcom since 1969. It is measured as the quantity (number of micromoles) of total nitrogen (i.e., nitrogen in all chemical forms) per unit volume of a water column, i.e., $\mu \mathrm{mol} /$ liter. Since we are interested in the effect of nitrogen on cod catches and since cod is a demersal species, the value at maximum depth at the sea bottom is used. For this variable we have 8,332 observations for the period 1969-2011. The trend is shown in Figure 2.

Nitrogen is sampled at maximum depth and the concentration of nitrogen is expected to be higher in shallow waters. Since the share of samples in shallow waters has increased over the years, a simple mean over all observations would be biased. For this reason, we use a variable where we first calculate the mean for each depth every year, thus generating one observation per depth per year. We then calculate the mean value 
per year over the different depths, thus getting a time series with one value of the average nitrogen level for each year. Although some depths are missing for some years (which will cause a bias in the estimate), this is not considered a major problem.

Figure 2: Nitrogen concentration $(\mu \mathrm{mol} / \mathrm{l})$ in the Western part of the Baltic Sea, $1985-2010$

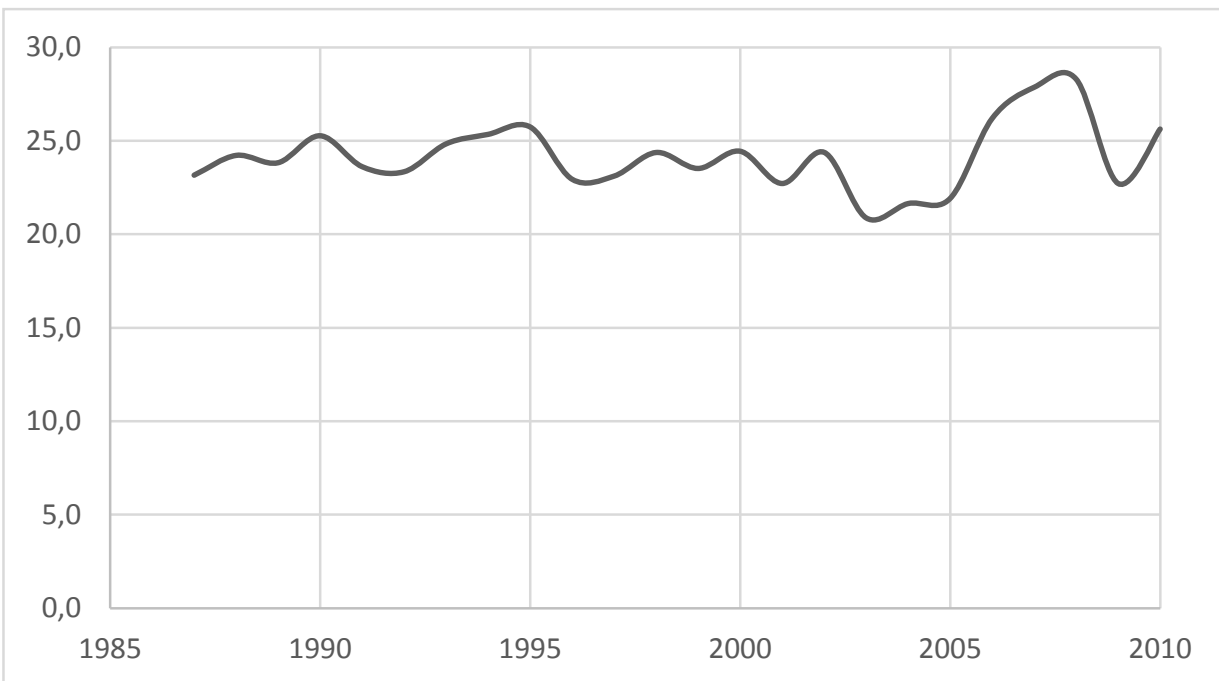

Nitrogen concentrations in the Western part of the Baltic Sea were relatively constant in the period 1987-2010, although with larger fluctuations in the end of the period. The relatively constant level of nitrogen concentration occurred despite of losses of nitrogen from several of the countries surrounding the Baltic Sea being reduced by more than half within the period, indicating that reduced losses decrease the concentrations in water with a substantial time lag.

\subsection{Results}

Before the welfare analysis can be performed, it is necessary to calibrate the parameters of the harvest function in ( 14 in appendix A) for the West Baltic cod stock. The model is calibrated first using information about the MSY level of the stock known from ICES advice, and then information on the level of nitrogen that induce the largest catch $(N *$ in Figure $1 b)$, which has been estimated based on estimated harvest and nitrogen concentrations. 
The calibration of the full model, discussed above, is based on the following assumptions: i) fishing mortality is sustainable in the start year, 2010, meaning that harvest in 2010 for the whole West Baltic cod stock is 14,120 tons (ICES, 2012) using an effort of 30,988 fishing days (The Danish AgriFish Agency, 2012), and an average nutrient concentration in 2010 of $25.6 \mu \mathrm{mol} / \mathrm{l}$ (ICES Dataset on Ocean Hydrography, 2011); ii) the effort corresponding to MSY is 34,549 fishing days in 2010, calculated based on ICES (2012), where the current biomass of 25,600 tons is $11 \%$ higher than the biomass corresponding to MSY of 23,000 tons, thus assuming that the current effort is $11 \%$ lower than the effort corresponding to MSY; iii) the harvest peak of nitrogen ( $N *$ in Figure $1 b$ ), is estimated to be $23.6 \mu \mathrm{mol} / \mathrm{l}$ (see below); and iv) For the fishing effort corresponding to $M S Y$ it holds that when nitrogen concentration in the sea is zero, it also holds that harvest of cod is zero. ${ }^{1}$

The level of nitrogen that induce the largest catch $\left(N^{*}\right)$ is identified in a regression analysis using the following particular form of the regression equation: $h=a_{0}+a_{1} N^{2}+$ $a_{2} N$, given unchanged fishing effort and with $a_{1}<0$ (cf. figure $1 b$ ). The model is estimated on the basis of annual catch data based on ICES (2012) and annual nitrogen concentrations in the Western part of the Baltic Sea from Figure 2.2. It is found that $a_{0}=240,640$, $a_{1}=-484$, and $a_{2}=22,819$. Hence, $N^{*}=-a_{2} / 2 a_{1}=23.6 \mu \mathrm{mol} / \mathrm{l}$.

On the basis of the four claims and given the simple form of the harvest equation (14) in appendix A, we have four linearly independent equations with four unknowns, meaning that we can identify the parameters unambiguously. The results are reported in Table 3 (parameters corresponding to parameters in equation 14 in Appendix A) and the subsequent results rely on these calibrations.

Table 3: Calibrated parameter values of the sustainable yield function of (14 in appendix A)

$\begin{array}{lr}\text { Parameter } & \text { Value } \\ \text { A } & 0.41583 \\ \text { B } & -0.00001 \\ \text { C } & 0.03526 \\ \text { d } & -0.00075\end{array}$

${ }^{1}$ The assumption that $\mathrm{h}=\mathrm{o}$ at this effort level is arbitrary, but is consistent with the notion that harvests are small when there is no human-induced nitrogen. 
In scenario 1 , the welfare contribution is maximized with respect to effort under unchanged nitrogen concentration, whereas welfare is maximized with respect to nitrogen concentration in scenario 2, given unchanged effort. In scenario 3, welfare is maximized varying both effort and nitrogen concentration.

Based on the calculated parameters, the results of welfare maximization under three scenarios are shown in Table 4. It must be emphasized that maximizations are performed both independently for the two national fleets, thus maximizing the welfare contribution of one fleet assuming that relative effort between the two fleets remains constant (resulting in the "Sweden" and "Denmark" cases in table 4), and for the two fleets simultaneously, again given the historical relative allocation of effort (resulting in the "Total" case in table 4). 
Table 4: Maximizing welfare contribution of Swedish and Danish cod fishery with passive gears in the Western part of the Baltic Sea, under the three scenarios

\begin{tabular}{|c|c|c|c|c|}
\hline & \multirow[t]{2}{*}{ Baseline } & \multicolumn{3}{|c|}{ Scenario of maximizing welfare by } \\
\hline & & $\begin{array}{l}\text { 1. Varying effort with } \\
\text { current nitrogen }\end{array}$ & $\begin{array}{l}\text { 2. Varying nitrogen } \\
\text { with current effort }\end{array}$ & $\begin{array}{l}\text { 3. Varying effort } \\
\text { and nitrogen }\end{array}$ \\
\hline \multicolumn{5}{|l|}{ Sweden } \\
\hline Welfare contribution (EUR million) & -1.51 & 0.12 & -1.46 & 0.12 \\
\hline Number of vessels & 55 & 8 & 55 & 8 \\
\hline Effort of segment (days-at-sea) & 5,306 & 811 & 5,306 & 815 \\
\hline Nitrogen $(\mu \mathrm{mol} / \mathrm{l})$ & 25.63 & 25.63 & 23.60 & 23.60 \\
\hline Landings (tons) & 523 & 135 & 526 & 136 \\
\hline Change in effort & . & -85 & 0 & -85 \\
\hline \multicolumn{5}{|l|}{ Denmark } \\
\hline Welfare contribution (EUR million) & -0.05 & 0.47 & -0.04 & 0.47 \\
\hline Number of vessels & 26 & 11 & 26 & 11 \\
\hline Effort of segment (days at sea) & 2,600 & 1,131 & 2,600 & 1,134 \\
\hline Nitrogen $(\mu \mathrm{mol} / \mathrm{l})$ & 25.63 & 25.63 & 23.59 & 23.59 \\
\hline Landings ( 1,000 tonnes) & 515 & 328 & 519 & 330 \\
\hline Change in effort & & -57 & 0 & -56 \\
\hline \multicolumn{5}{|l|}{ Total } \\
\hline Welfare contribution (EUR million) & -1.59 & 0.61 & -1.57 & 0.61 \\
\hline Number of vessels & 81 & 24 & 81 & 24 \\
\hline Effort of segment (days at sea) & 13,406 & 3,898 & 13,406 & 3,918 \\
\hline Nitrogen $(\mu \mathrm{mol} / \mathrm{l})$ & 25.63 & 25.63 & 23.59 & 23.59 \\
\hline Landings (tons) & 1,038 & 477 & 1,045 & 481 \\
\hline Change in effort & & -71 & 0 & -71 \\
\hline
\end{tabular}

Welfare contribution is negative in the current situation, i.e., the fisheries generate a lower welfare contribution to society than if labor and capital had been used in alternative sectors. When welfare is maximized simultaneously for vessels from both countries, referred to as "Total" in Table 4, varying the effort level only, with the current level of nitrogen (scenario 1), would result in a welfare contribution of EUR 610,000. The number of vessels would decrease from 81 to 24 , effort would decrease by $71 \%$, and landings would decrease to less than half the landings in the current situation. 
For the separate optimization of the Danish and Swedish fleets, there is a small welfare contribution when the nitrogen concentration is optimized while keeping effort constant (scenario 2), as landings increase by 7 tons. When varying both the level of effort and nitrogen (scenario 3 ), the difference in maximum welfare contribution is very small compared with the situation where only the level of effort is changed (scenario 1 ). Although it is not visible in Table 4, it amounts to EUR 4,555. Comparing scenarios 1 and 3, effort increases slightly, by 20 days at sea, and landings are 4 tons higher, indicating that if this fishery was economically efficient, reducing the nitrogen level would have a positive, but very small, effect (0.001\% of the landing value).

For the Swedish fleet, the current (2010) welfare contribution is negative. This implies that despite revenues of EUR 2.3 million, the costs (including opportunity costs of capital and labor) are too high to generate a positive welfare contribution to society from this fishery. As shown for scenario 1 , the situation changes if the welfare contribution is maximized, although this makes most of the vessels redundant. Only eight of original 55 vessels remain after maximizing the welfare contribution by varying effort. Effort decreases by $85 \%$ and landings of cod are reduced by 388 tons.

The effect of moving to the optimal level of nitrogen, without changing effort (scenario 2), is negligible compared with scenario $1_{i}$ the welfare contribution improves somewhat as the landings of cod increase by 3 tons, but is still negative. Scenario 3 measures the effect of maximizing welfare contribution by varying effort, as well as letting the nitrogen level reach its optimum. The difference between this situation and that of only maximizing with respect to effort is small. The additional effect on the welfare contribution is not visible in the table, but amounts to EUR 744 .

For the Danish fleet the current welfare contribution is slightly negative, around EUR 50,000. As a comparison, the value of landings for this segment is EUR 3.2 million. Compared with the Swedish fleet, the financial situation is better in the current situation. Maximizing the welfare contribution by varying the level of effort (scenario 1) gives a positive welfare contribution. The number of vessels decreases to less than half and effort decreases by $57 \%$. As is the case for the Swedish vessels, adjusting the nitrogen level to its optimum while keeping effort unchanged (scenario 2 ) has a very small effect on the welfare contribution. The welfare contribution becomes slightly less negative, as the landings increase by 4,000 tons. Finally, varying the level of nitrogen simultaneously with the effort level (scenario 3 ) gives a small additional increase in welfare contribution (around EUR 2,300, not shown in Table 4).

The results indicate that substantial welfare gains can be achieved by reducing effort, but that changing the nitrogen concentration is of little importance for the optimal fleet size and for the welfare contribution of the fishery. Hence, from a fishery sector perspective, the results indicate that there might be a limited need for spending time 
on changing the nitrogen concentrations in the Western part of the Baltic Sea. If, however, environmental policies that reduce nitrogen concentrations are implemented, this will potentially affect the optimal fleet size and the welfare contribution of the cod fishery. The effect of reducing nitrogen concentrations is shown in Table 5 , i.e., the table shows the optimal outcome for the total fishery (Danish and Swedish fleets together) when welfare is maximized with respect to effort, while keeping the nitrogen level at the constant, but decreasing, levels shown in the table.

\begin{tabular}{|c|c|c|c|c|c|c|c|c|c|c|c|}
\hline & Current & $-10 \%$ & $-20 \%$ & $-30 \%$ & $-40 \%$ & $-50 \%$ & $-60 \%$ & $-70 \%$ & $-80 \%$ & $-90 \%$ & $-95 \%$ \\
\hline $\begin{array}{l}\text { Welfare } \\
\text { contribu- } \\
\text { tion, EUR } \\
\text { million }\end{array}$ & 0.61 & 0.61 & 0.60 & 0.58 & 0.54 & 0.49 & 0.44 & 0.37 & 0.31 & 0.24 & 0.21 \\
\hline $\begin{array}{l}\text { Number of } \\
\text { vessels }\end{array}$ & 24 & 24 & 23 & 23 & 22 & 21 & 19 & 17 & 15 & 13 & 12 \\
\hline $\begin{array}{l}\text { Effort of } \\
\text { segment } \\
\text { (days at sea) }\end{array}$ & 3,898 & 3,916 & 3,874 & 3,771 & 3,610 & 3,395 & 3,130 & 2,823 & 2,480 & 2,114 & 1,925 \\
\hline $\begin{array}{l}\text { Nitrogen } \\
(\mu \mathrm{mol} / \mathrm{l})\end{array}$ & 25.63 & 23.07 & 20.51 & 17.94 & 15.38 & 12.82 & 10.25 & 7.69 & 5.13 & 2.56 & 1.28 \\
\hline $\begin{array}{l}\text { Landings } \\
\text { (tonnes) }\end{array}$ & 477 & 481 & 472 & 450 & 418 & 375 & 325 & 271 & 214 & 159 & 133 \\
\hline $\begin{array}{l}\text { Change in } \\
\text { effort }\end{array}$ & -71 & -71 & -71 & -72 & -73 & -75 & -77 & -79 & -81 & -84 & -86 \\
\hline
\end{tabular}

Table 5 shows the effect on the total fishery when the nitrogen level is reduced from its current level. For example, if the nitrogen level is reduced by $50 \%$, the welfare contribution will fall from EUR 0.61 million to EUR 0.49 million. As above, the optimal nitrogen level is reached when the nitrogen level is reduced by $8 \%$ compared to the current level. Reducing the level of nitrogen more than to $\mathrm{N} *$ will reduce the number of vessels, the effort, and the landings. The changes are rather small overall, however. For example, reducing the level of nitrogen by $50 \%$ (from the current $25.6 \mu \mathrm{mol} / \mathrm{l}$ to $12.82 \mu \mathrm{mol} / \mathrm{l}$ ) would correspond to a reduction in welfare contribution of EUR 120,000, the removal of three vessels, and a reduction in landings of 102 tons. This can be compared with the difference of EUR 3.2 million in welfare contribution, 57 vessels, and 561 tons landings between the current situation and the economically efficient situation. Furthermore, a 
reduction of the optimal fleet size by $50 \%$ requires a reduction in the nitrogen concentration of $95 \%$. Hence, except for very large reductions in nitrogen, the effect of nitrogen on the optimal fleet size and welfare is negligible.

The implications of these results are that the water environment policies regulating nitrogen are not of great importance for the West Baltic cod fishery. However, these results are produced without analyzing whether it is possible to reduce concentrations and without analyzing how it can be done. The results are obtained assuming that reduction is actually possible, leading to the finding that at reasonable reductions the effect is very small.

Since the optimal level of nitrogen, $N *$, is identified with uncertainty, a sensitivity analysis is required. The results for scenario 3 are shown in Table 6, where the optimal nitrogen level is varied by $+/-40,+/-30,+/-20$, and $+/-10 \%$.

Table 6: Effect of varying the optimal nitrogen level, $\mathrm{N} *$, by $+/-40,30,20$, and $10 \%$ on the Swedish and Danish fleets

\begin{tabular}{|c|c|c|c|c|c|c|c|c|c|}
\hline & $40 \%$ & $30 \%$ & $20 \%$ & $10 \%$ & $0 \%$ & $-10 \%$ & $-20 \%$ & $-30 \%$ & $-40 \%$ \\
\hline $\begin{array}{l}\text { Welfare contribution, } \\
\text { EUR million }\end{array}$ & 0.65 & 0.63 & 0.61 & 0.60 & 0.61 & 0.65 & 0.75 & 1.05 & 2.78 \\
\hline Number of vessels & 25 & 24 & 24 & 24 & 24 & 24 & 26 & 32 & 48 \\
\hline $\begin{array}{l}\text { Effort of segment (days } \\
\text { at sea) }\end{array}$ & 4,073 & 3,988 & 3,924 & 3,893 & 3,918 & 4,043 & 4,378 & 5,242 & 7,993 \\
\hline Nitrogen $(\mu \mathrm{mol} / \mathrm{l})$ & 33.02 & 30.66 & 28.30 & 25.95 & 23.59 & 21.23 & 18.87 & 16.51 & 14.15 \\
\hline Landings (tons) & 518 & 498 & 483 & 475 & 481 & 511 & 593 & 837 & 2021 \\
\hline Change in effort & -70 & -70 & -71 & -71 & -71 & -70 & -67 & -61 & -40 \\
\hline
\end{tabular}

Increasing the optimal nitrogen level has small effects on welfare contribution in most cases. Even if the optimum is assumed to be $40 \%$ larger than found above, the welfare contribution does not change by more than EUR 40,000. On the other hand, if we have overestimated the optimal nitrogen level the effects are somewhat larger. The welfare contribution increases by EUR 2.13 million if it is assumed that the optimal nitrogen level is $40 \%$ lower than that used in the previous analysis. Hence, the results are relative robust while changing $\mathrm{N} *$ by $+/-20 \%$, and underestimate the fleet size considerably only if the true $\mathrm{N} *$ is $40 \%$ lower than found above. 


\subsection{Conclusions}

In this chapter, a model is developed to identify optimal management of fisheries under the influence of nutrients. The model is applied to the Swedish and Danish cod fisheries using passive gears in the Western part of the Baltic Sea under the influence of different levels of nitrogen. The results show that the welfare contribution of fisheries is $-28 \%$ of the landing value in 2010 . The model shows that a welfare contribution of $11 \%$ could be reached if effort levels and nitrogen concentration are reduced. The initial negative welfare contribution indicates that labor and capital used in these fisheries segments have greater value when used in alternative sectors. These optima are achieved by reducing the number of vessels from 81 to 24 , when maximizing with respect to both fishing effort and fishing effort/nitrogen. Maximizing welfare contribution of the fleets of the two countries separately leads to a greater fleet reduction for Sweden (from 55 to 8 vessels) than for Denmark (from 26 to 11 vessels). This is explained by the fact that a vessel quota share regulation was implemented in Denmark in 2007, whereas under Swedish regulations the coastal fishery has no quota limitations. The potential for reducing the Swedish fleet is substantial, but there is also some potential for reducing the Danish fleet, since structural adjustment can take a long time and is probably not completed in Denmark.

On this basis, it is concluded that substantial welfare gains can be achieved by reducing fishing effort, but that the additional welfare gain from reducing the nitrogen concentration to the optimal level is largely non-existent. This limited effect on welfare contribution of incorporating nitrogen in the fishery policy is achieved for a marine area (the Baltic Sea) with one of the highest concentration of nutrients worldwide. Hence, the results indicate that nutrients need not be a major concern in fisheries.

The analysis also shows that if environmental policy were to require a reduction in nitrogen emissions, a $50 \%$ reduction in nitrogen concentration would reduce the maximum welfare to $9 \%$ of the landing value, compared with $11 \%$ without a reduction in nitrogen. Again, the effect of environmental policy on fisheries is not large. However, annual nitrogen emissions have been reduced by up to half since the 1980 in many of the countries surrounding the Baltic Sea but nitrogen concentrations in Baltic Sea water have until recently been largely unaffected. Hence, reducing nitrogen concentrations takes a long time.

The theoretical discussion on the influence of nutrients on fisheries reveals a potential conflict between fisheries policy and environmental policy. The results confirm the conflicting objectives of maximizing welfare contribution of fisheries and conservation of benthic ecosystems through control of nutrient discharges, but only at nutrient concentrations below the level ensuring the maximum steady-state fish stock. At 
higher concentrations, the two policies have similar objectives. At low nutrient concentrations, however, the extra effect of incorporating nitrogen in the fisheries policy on the welfare contribution of fisheries is small, indicating that the conflict between the two policies is indeed small. Thus, at reasonably high levels of $\mathrm{N}$, a reduction in nutrient concentrations in order to improve the environmental status of the Baltic Sea will only marginally influence fishing.

This analysis of the influence of nutrients on fisheries also reveals that the rationale for having fisheries following agriculture and deliberately controlling the optimal level of fertilization of the seas is very limited, owing to the small effect of nutrients on welfare creation in fisheries. Hence, welfare considerations are another reason for not deliberately controlling the level of fertilization of the sea, together with risks of degradation leading to lack of resilience of benthic ecosystems, lack of knowledge on the functioning of ecosystems, and inability to control complex ecosystem functions even in simple ecosystems.

The inclusion of nutrients when modeling exploitation of the cod stock may significantly impact prey stocks in the ecosystem. This effect is neglected in the current analysis. Although such inclusion might increase the accuracy of the results, the policy implication will remain unchanged. The reason is that the prey stocks, herring and sprat, are pelagic species that migrate and therefore are less exposed to oxygen depletion. Hence, while a reduction in the number of vessels would result in a large welfare gain, it is of less importance what happens to nutrients. 


\section{Case II: Influence of nutrients on growth of salmon at marine fish farms in the Bokna Fiord in Norway}

\section{$2.1 \quad$ Introduction}

The purpose of this chapter is to investigate whether and how nitrogen affects growth of farmed fish in Nordic aquaculture, focusing at the case of salmon farming in the Bokna Fiord. Bokna Fiord is chosen for analysis since it is in Southern Norway where water temperatures are higher, inducing the highest risk of causing hypoxia. The chapter is founded in production economics and applies regression analysis. This case study is performed by Professor Frank Asche and Jay Abolofia from University of Stavanger, Norway.

\subsection{Background and purpose}

Aquaculture is the world's fastest growing food production technology (FAO, 2014) and salmon aquaculture is among the most successful with production growth rates even higher than for aquaculture on average. The development in quantity produced as well as the real price is shown in figure 3 . 
Figure 3: Global Atlantic salmon production and real Norwegian export price

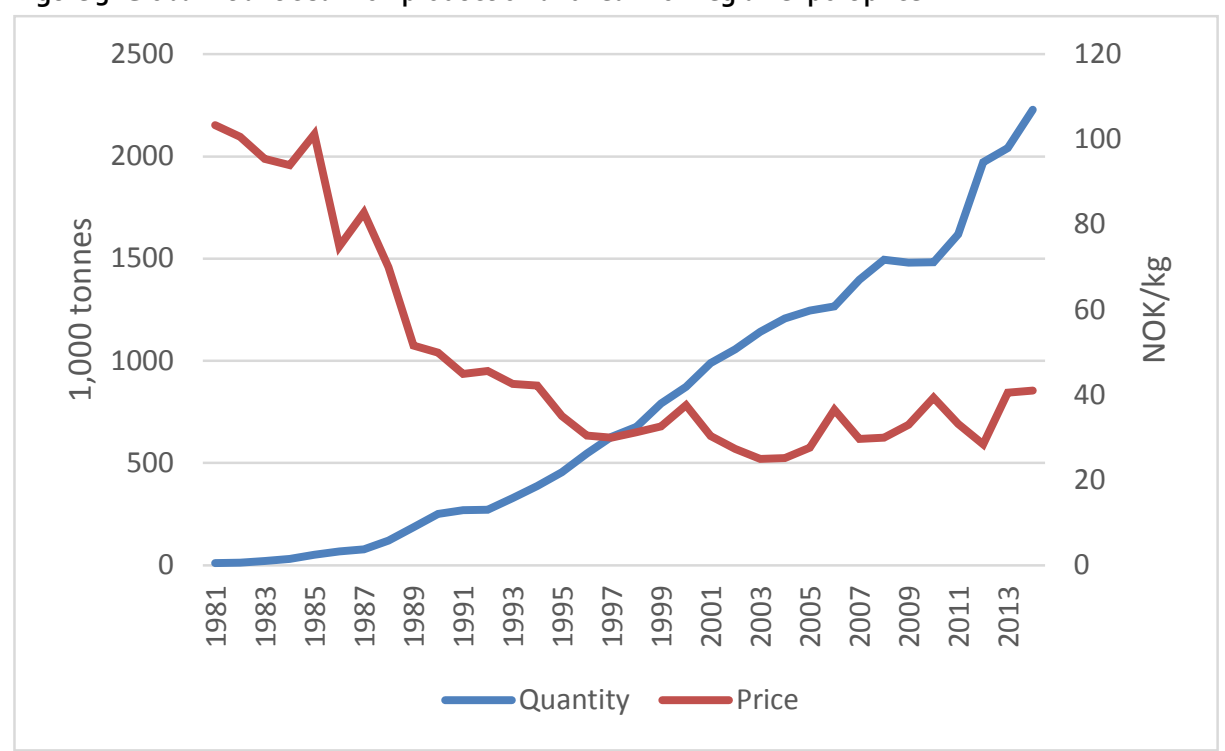

Source: Directorate of Fisheries and Norwegian Seafood Council.

As one can see, production increased from a few thousand tons in the early 1980 s to over 2 million tons in 2013. Norway is the largest producer with around $60 \%$ of the production followed by Chile with about $25 \%$.

Increased productivity due to a number of innovations is the most important factor fueling this growth (Asche, 1997). A number of studies have provided insights with respect to the sources for this productivity growth; recent examples include Tveterås and Batteese (2006), Andersen, Roll and Tveterås (2008), Asche, Roll and Tveterås (2009), Nilsen (2010), Aasheim et al. (2011), Vassdal and Holst (2011), Roll (2013), Asche and Roll (2013) and Asche, Guttormsen and Nielsen (2013). This development is due to productivity growth at the farms themselves, but innovations throughout the supply chain is of equal importance as it is total cost of bringing the product to the consumer that determines the competitiveness of a product.

Sea cage aquaculture, which is the dominating technology in salmon aquaculture, is also a new way of using the coastal environment, and interactions between the environment and the farms influence productivity at the farm and creates potential negative environmental externalities. Important factors include low dissolved oxygen levels creating hypoxic conditions in the pens (Johansson et al., 2006) and algae blooms that are triggered by high nutrient loadings and low levels of dissolved oxygen (Johnsen and Sakshaug, 2000). There is a debate in Norway with respect to the 
extent that human activity and the salmon industry itself is at least partly to blame for these challenges. KLIF (2010) indicate that the salmon industry is the largest human source for nutrients along the Norwegian coast. However, IMR (2011) indicates that human is such a limited source of nutrients relative to natural sources that it does not matter for the ecosystem. ${ }^{2}$

Asche, Guttormsen and Tveterås (1999) argue that salmon farmers facing adverse environmental conditions that reduce productivity have incentives to introduce innovations in order to avoid these effects. Hypoxia and algae blooms were severe challenges in the 1990s (Johnsen and Sakshaug, 2000), but the challenge seems to have abated. There are at least two possible reasons for that. First, nutrients discharges from the salmon industry have been substantially reduced (Tveterås, 2002; Asche and Bjørndal, 2011). This has, together with fallowing requirements improved environmental conditions in the vicinity of the farms and removed local sources for dissolved oxygen, as well as reduced the total impact of nutrients from aquaculture on the ecosystem. In addition, improved cages have allowed the farms to be moved to more exposed locations with better water circulation (Asche and Bjørndal, 2011). Thisd reduces the likelihood of hypoxic conditions as well as their duration. Finally, the sea cages have become much larger (Asche et al., 2013). Averaged depth in 1980 was 4 meters and diameter was 5 meter, compared to 40 meters and 40 meters in 2010. This means that there is now substantial variation in environments within the pens (Oppedal, Dempster, and Stien, 2011). This enables the fish to avoid hypoxic areas in the pens.

In this chapter we will investigate whether nutrient levels as measured by nitrogen loading is the main factor that cause hypoxia, and thus influence growth rates in salmon farming, using data for the Bokna Fiord. This is the southernmost area with substantial salmon farming activities and one of the areas with most hypoxia and algae bloom challenges in the 1990s. As a consequence, regular measurement of nitrogen loading is available for several years.

\subsection{Production process and data}

The production process for farmed salmon is, in principle, fairly simple. At a hatchery, the salmon eggs and fry are nurtured in freshwater tanks. Between 8 and 14 months after they hatch, smolts are transferred to pens (or sea cages) immersed in salt water (Sandvold and Tveterås, 2014). There, the fish are fed for up to two years. Salmon can be harvested

2 This is in contrast to e.g. Danish aquaculture, where nitrogen discharges is the most constraining factor with respect to growth (Nielsen 2012). 
at a weight of 1-2 kilos, but are usually harvested at larger sizes. Most common are harvesting weight of $4-5$ kilos (Asche and Guttormsen, 2001).

As salmon is farmed in open cages in seawater, it is exposed to the ecosystem around the farm. This provides services such as oxygen and nutrient discharge including that of feces, but also provides challenges such as fish diseases, toxic algae, and other harmful substances. The industry has been subject to large economic losses because of these environmental factors, but also causes substantial environmental externalities (Tveterås 2002; Torrissen et al., 2011; 2013).

The data covers all salmonid producing farms in Rogaland from May 2010 through Dec 2013. Figure 4 shows the geographical location of each producing farm (red points) and nutrient monitoring station (blue points) in Rogaland during the period in question. Monthly farm-level summary statistics are shown in Table 7 and include average seawater temperature at 3 meters, average fish weight, standing level of fish biomass (as reported at the end of each month), fish species, geographical coordinates, and the level of ammonium nitrogen, nitrate and total nitrogen reported at the nearest nutrient monitoring station. ${ }^{3}$

3 Using geographical coordinates, we calculate the distant between each farm and nutrient monitoring station and identify the station that is nearest to each farm. 
Table 7: Monthly Farm-level Summary Statistics (Rogaland, May 2010-Dec 2013)

\begin{tabular}{|c|c|c|c|c|c|c|}
\hline Variable & Observations & Farms & Mean & Std. Dev. & $\mathrm{P}_{5}{ }^{\mathrm{a}}$ & P95 \\
\hline Seawater temperature $\left({ }^{\circ} \mathrm{C}\right)^{b}$ & 1028 & 61 & 9.87 & 4.07 & 3.28 & 16.00 \\
\hline Number of fish released & 2001 & 61 & 38.99 & 139.59 & 0 & 352.70 \\
\hline Number of fish & 1999 & 61 & $5 \cdot 37$ & 3.57 & 0.02 & 11.13 \\
\hline Avg. fish weight (kg) & 1903 & 61 & 2.18 & 2.07 & 0.12 & 5.80 \\
\hline Fish biomass (kg) & 1999 & 61 & 907.69 & 898.27 & 1.49 & $2,739.64$ \\
\hline Feed use (tonnes) & 1961 & 60 & 1.79 & 1.74 & 0.02 & $5 \cdot 38$ \\
\hline No. of fish mortalities & 1997 & 61 & 6.76 & 16.30 & 0.09 & 26.28 \\
\hline No.of fish removals & 1997 & 61 & 627.80 & $2,320.62$ & 0 & $4,007.00$ \\
\hline No.of fish escapes & 1997 & 61 & 1.81 & 80.83 & o & 0 \\
\hline No.of miscellaneous fish losses & 1997 & 61 & 27.82 & 401.48 & o & 22.00 \\
\hline No.of fish harvested & 1997 & 61 & 33.13 & 91.71 & 0 & 201.65 \\
\hline Avg. harvested fish weight $(\mathrm{kg})$ & 511 & 61 & 3.92 & 1.71 & 0.22 & 6.18 \\
\hline Harvested fish biomass (kg) & 1997 & 61 & 122.61 & 298.39 & o & 809.73 \\
\hline Ammonium nitrogen (mg/L) & 2630 & 75 & 11.93 & 8.24 & 3.00 & 29.75 \\
\hline Nitrate (mg/L) & 2630 & 75 & 30.36 & 37.66 & 1 & 120.00 \\
\hline Total nitrogen (mg/L) & 2630 & 75 & 156.52 & 51.28 & 86.25 & $247 \cdot 50$ \\
\hline Atlantic salmon (dummy) & 2001 & 61 & 1 & o & 1 & 1 \\
\hline Rainbow trout (dummy) & 2001 & 61 & o & o & 0 & 0 \\
\hline Latitude (decimal degrees) & 3300 & 75 & 59.26 & 0.19 & 58.91 & $59 \cdot 55$ \\
\hline Longitude (decimal degrees) & 3300 & 75 & 5.84 & 0.31 & 5.17 & 6.29 \\
\hline
\end{tabular}

Note: $\quad \mathrm{a}_{5}$ is 5 th percentile of data; $\mathrm{P}_{95}$ is 95 th percentile of data.

b Levels reported for May 2010-Feb 2012 only. 
Figure 4: Regions of Norway with Rogaland highlighted in dark green.Municipalities of Rogaland with actively producing farms in red and nutrient monitoring stations in blue (May 2010-Dec 2013)

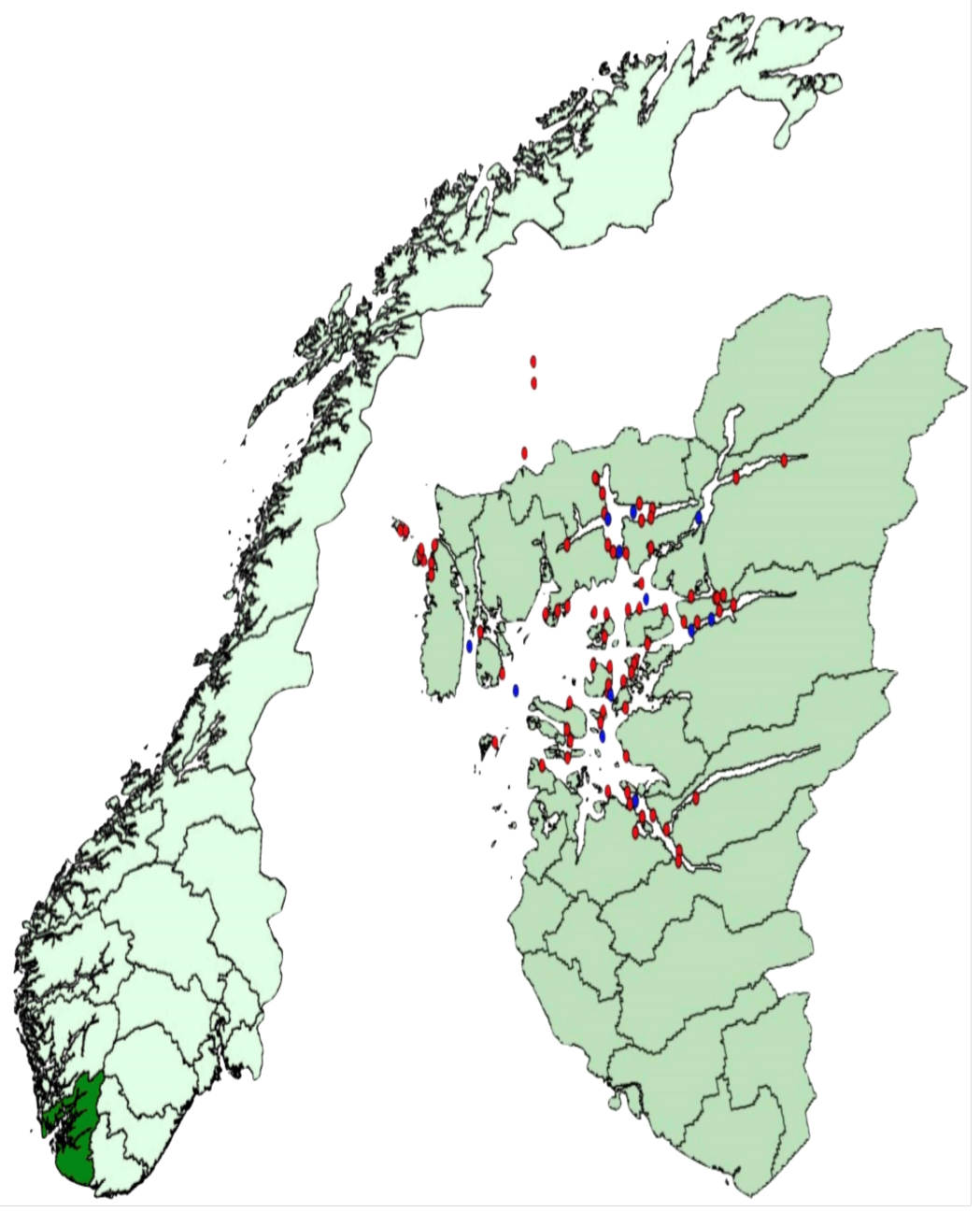

Figure 5 plots the mean farm levels of ammonium nitrogen, nitrate, total nitrogen and seawater temperature by month and over time. The dashed red line, in the final figure, illustrates the imputed temperature values used in model specification [2]. The top row of Figure 5 highlights the seasonality of nitrate and total nitrogen levels, and apparent lack of seasonality of ammonium nitrogen levels; while the bottom row highlights the seasonality of average monthly seawater temperatures. 
Figure 5: Average nitrogen levels and seawater temperatures by month (column 1) and overtime (column 2) for all producing salmonid farms in Rogaland, Norway (May 2010-Dec 2013)
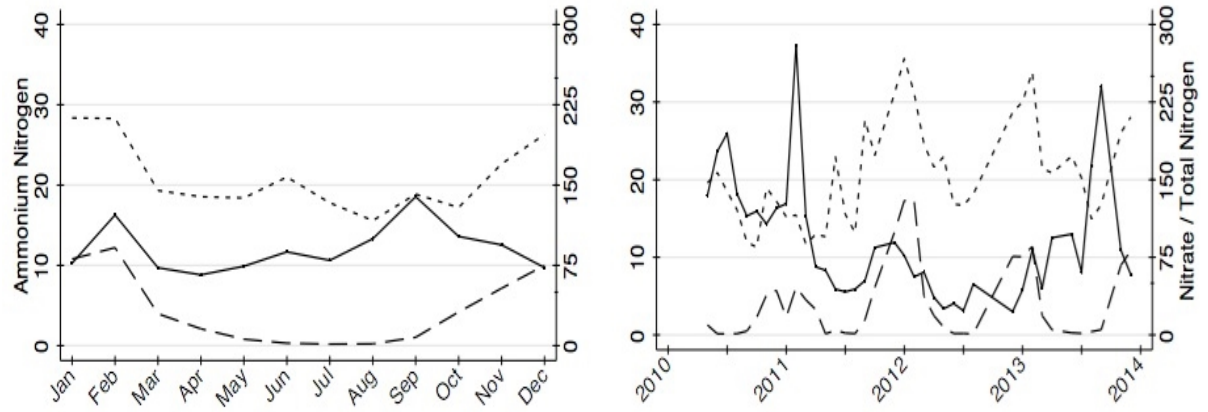

Ammonium Nitrogen - - - - Nitrate

......... Total Nitrogen
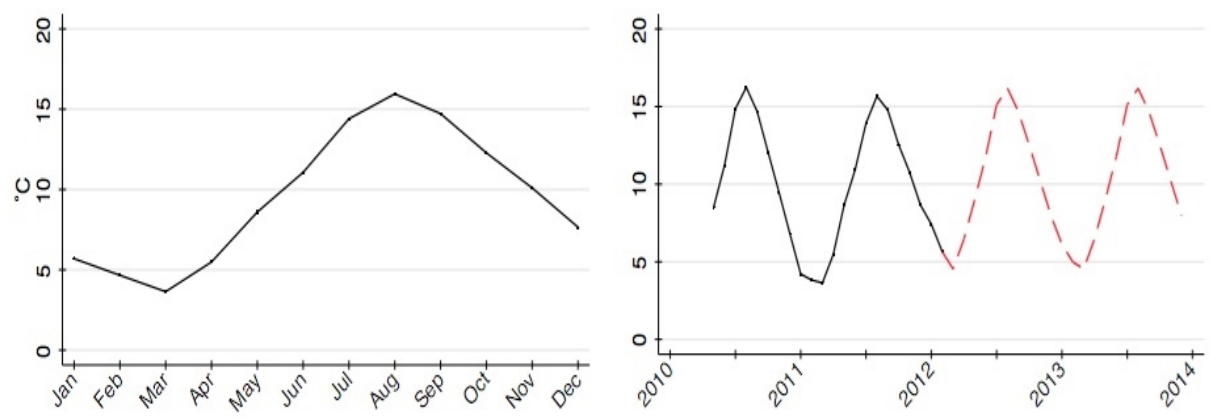

Reported Temp

- - - Imputed Temp

Figures 6 and 7 provide a better understanding of salmonid production in Rogaland over time. Specifically, Figure 6 plots the level of yearly salmonid production (i.e., total harvested biomass) since 2005, and Figure 7 plots the farm level monthly averages of standing fish biomass and number of fish released. Figure 6 shows how production levels in Rogaland have grown over time, such that levels in 2013 are almost double what they were in 2005. Figure 7 shows both the seasonality and monthly trend of stocking and biomass levels, highlighting that farms in Rogaland typically stock their fish in the spring or fall while biomass levels rise during the warmer months when fish grow is most rapid. 
Figure 6: Total harvested salmonid biomass by year (Rogaland, 2005-2013)

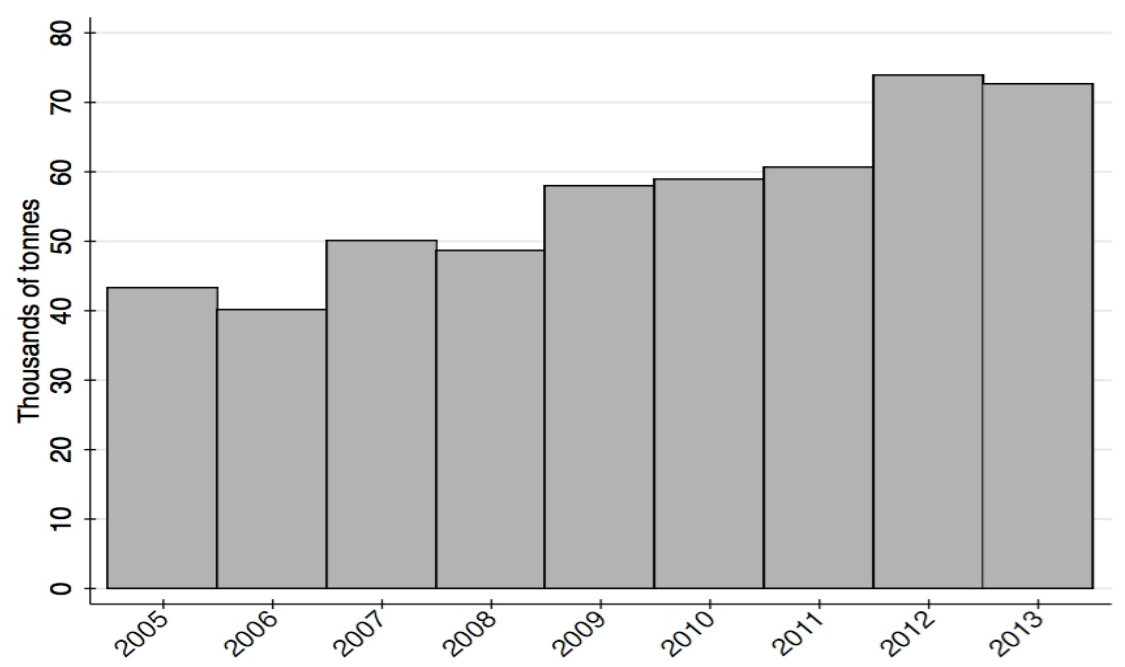

Figure 7: Average number of fish released and standing biomass by month (row 1) and overtime (row 2) for all producing salmonid farms in Rogaland, Norway (May 2010-Dec 2013)
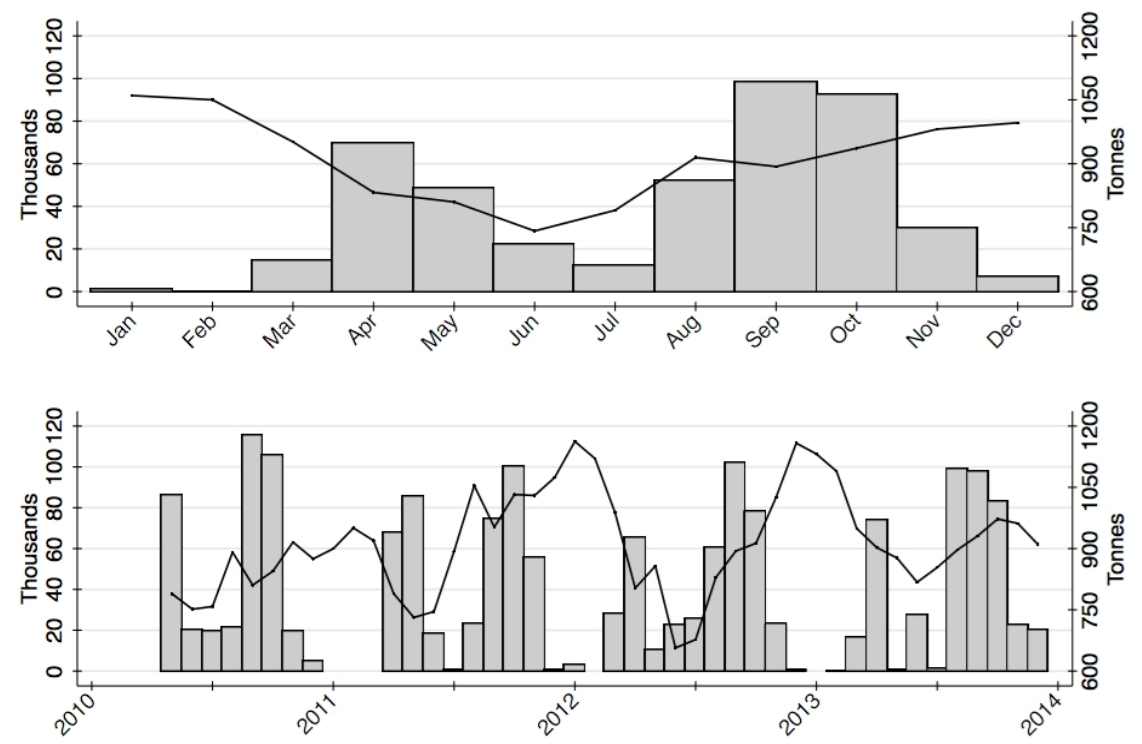

No. of Fish Released

Standing Biomass 


\subsection{Estimation model}

To test whether changed levels of nitrogen in seawater have a statistically significant effect on the biological growth of farmed salmonids (i.e., salmon and trout), we estimate an empirical model of the rate of fish biomass growth following previous work by $A b$ olofia, Asche and Wilen (2014), and Abolofia (2014). This is based on the standard harvesting model, but extended to allow for the impact of biophysical factors. Specifically, we model the biological growth rate of fish biomass $\left(r_{i t}\right)$ as an exponential function of farmspecific time dependent explanatory variables, including the level of nitrogen (e.g., ammonium nitrogen, nitrate, or total nitrogen) measured by the nearest nutrient monitoring station The estimation model is described in appendix B. ${ }^{4}$

Because seawater temperature data is not available between Feb 2012 and Dec 2013, we run two alternative model specifications: specification [1] employs the reported seawater temperatures from May 2010 to Feb 2012, while specification [2] systematically replaces the missing seawater temperature values (Mar 2012 to Dec 2013) with the appropriate month-specific average in Rogaland between Jan 2005 and Feb 2012. In short, specification [2] uses both reported and imputed values of seawater temperature in order to expand upon the number of observations used in the estimation procedure of specification [1].

\subsection{Results}

Based on the above estimation model, we investigate whether higher levels of ammonium nitrogen, nitrate, or total nitrogen have a statistically significant effect on the biological growth of farmed salmonids using 3 separate models - each of which is estimated using the 2 specifications discussed above. Specifically, Tables 8-10 provide parameter estimates for each of our models: ammonium nitrogen, nitrate, and total nitrogen respectively.

4 Our model structurally accounts for all month-to-month changes in biomass unrelated to fish growth (i.e., stocking, harvesting, mortalities, removals and escapes). 
Table 8: Model Results for Ammonium Nitrogen

\begin{tabular}{|c|c|c|c|c|}
\hline \multirow[b]{2}{*}{ Variable } & \multicolumn{2}{|c|}{ May 2010-Feb 2012} & \multicolumn{2}{|c|}{ May 2010-Dec $2013^{a}$} \\
\hline & Pooled OLS [1] & Fixed Effects [1] & Pooled OLS [2] & Fixed Effects [2] \\
\hline Feed $_{t}$ ('oos of tonnes) & $0.0119 *(0.0065)$ & $0.0224 *(0.0122)$ & $0.0161(0.0129)$ & $0.0179 *(0.0237)$ \\
\hline Avg. fish size $\mathrm{t}_{\mathrm{t}-1}(\mathrm{~kg})$ & $-0.0529 * *(0.0087)$ & $-0.0632 * *(0.0141)$ & $-0.0553 * *(0.0139)$ & $-0.0736 * *(0.0249)$ \\
\hline Seawater temp $p_{\mathrm{t}-1}\left({ }^{\circ} \mathrm{C}\right)$ & $0.0100 * *(0.0024)$ & $0.0089 * *(0.0029)$ & $0.0121 * *(0.0026)$ & $0.0107 * *(0.0032)$ \\
\hline Ammon. nitrogen ${ }_{t}$ & $0.0014(0.0015)$ & $0.0014(0.0016)$ & $0.0019(0.0018)$ & $0.0014(0.0019)$ \\
\hline Constant & $0.1471 * *(0.0353)$ & $0.1565 * *(0.0409)$ & $0.1117 * *(0.0478)$ & $0.1636 * *(0.0509)$ \\
\hline Farm fixed effects & NO & YES & NO & YES \\
\hline Observations & 832 & 832 & 1,382 & 1,382 \\
\hline No. of farms & 56 & 56 & 58 & 58 \\
\hline$B / C^{b}$ & -148 & -243 & 2,535 & 2,481 \\
\hline
\end{tabular}

Note: Standard errors in parentheses corrected for spatial/temporal correlations.

* p-value $<0.10 ; *$ * p-value $<0.05$.

a Seawater temperature values imputed for Mar 2012 to Dec 2013.

b Bayesian Information Criterion (BIC) is a statistical measure of model fit. 


\section{Table 9: Model Results for Nitrate}

\begin{tabular}{|c|c|c|c|c|}
\hline \multirow[b]{2}{*}{ Variable } & \multicolumn{2}{|c|}{ May 2010-Feb 2012} & \multicolumn{2}{|c|}{ May 2010-Dec $2013^{a}$} \\
\hline & Pooled OLS [1] & Fixed Effects [1] & Pooled OLS [2] & Fixed Effects [2] \\
\hline Feed $_{t}$ ('oos of tonnes) & $0.0114 *(0.0064)$ & $0.0215^{*}(0.0120)$ & $0.0169(0.0137)$ & $0.0188 *(0.0247)$ \\
\hline Avg. fish size $\mathrm{t}_{\mathrm{t}-1}(\mathrm{~kg})$ & $-0.0524 * *(0.0087)$ & $-0.0629 * *(0.0146)$ & $-0.055^{8 * *}(0.0144)$ & $-0.0743^{* *}(0.0257)$ \\
\hline Seawater temp $\mathrm{p}_{\mathrm{t}-1}\left({ }^{\circ} \mathrm{C}\right)$ & $0.0097 * *(0.0025)$ & $0.0085^{* *}(0.0030)$ & $0.0131 * *(0.0031)$ & $0.0115^{* *}(0.0033)$ \\
\hline Nitrate $_{t}$ & $-0.0002(0.0002)$ & $-0.0002(0.0002)$ & $0.0003(0.0004)$ & $0.0003(0.0005)$ \\
\hline Constant & $0.1750 * *(0.0290)$ & $0.1863^{* *}(0.0328)$ & $0.1120 * *(0.0539)$ & $0.1600 * *(0.0551)$ \\
\hline Farm fixed effects & NO & YES & NO & YES \\
\hline Observations & 832 & 832 & 1,382 & 1,382 \\
\hline No. of farms & 56 & 56 & 58 & 58 \\
\hline$B / C^{b}$ & -146 & -241 & 2,536 & 2,481 \\
\hline
\end{tabular}

Note: Standard errors in parentheses corrected for spatial/temporal correlations.

* p-value < $0.10 ; * *$-value $<0.05$.

a Seawater temperature values imputed for Mar 2012 to Dec 2013.

b Bayesian Information Criterion (BIC) is a statistical measure of model fit. 
Table 10: Model Results for Total Nitrogen

\begin{tabular}{|c|c|c|c|c|}
\hline \multirow[b]{2}{*}{ Variable } & \multicolumn{2}{|c|}{ May 2010-Feb 2012} & \multicolumn{2}{|c|}{ May 2010-Dec $2013^{a}$} \\
\hline & Pooled OLS [1] & Fixed Effects [1] & Pooled OLS [2] & Fixed Effects [2] \\
\hline Feed $_{t}$ ('oos of tonnes) & $0.0118 *(0.0063)$ & $0.0220 *(0.0118)$ & $0.0160(0.0128)$ & $0.0175^{*}(0.0233)$ \\
\hline Avg. fish size $\mathrm{t}_{\mathrm{t}-1}(\mathrm{~kg})$ & $-0.0526 * *(0.0086)$ & $-0.0633^{* *}(0.0143)$ & $-0.0551 * *(0.0136)$ & $-0.0733^{* *}(0.0245)$ \\
\hline $\begin{array}{l}\text { Seawater tempt- } \\
1\left({ }^{\circ} \mathrm{C}\right)\end{array}$ & $0.0099 * *(0.0025)$ & $0.0087 * *(0.0030)$ & $0.0125^{* *}(0.0026)$ & $0.0110 * *(0.0031)$ \\
\hline Total nitrogen $_{\mathrm{t}}$ & $-0.0001(0.0001)$ & $-0.0001(0.0001)$ & $-0.0002(0.0002)$ & $-0.0001(0.0002)$ \\
\hline Constant & $0.1757^{* *}(0.0284)$ & $0.1874 * *(0.0349)$ & $0.1581 * *(0.0280)$ & $0.1973 * *(0.0381)$ \\
\hline Farm fixed effects & NO & YES & NO & YES \\
\hline Observations & 832 & 832 & 1,382 & 1,382 \\
\hline No. of farms & 56 & 56 & 58 & $5^{8}$ \\
\hline$B I C^{b}$ & -146 & -240 & 2,536 & 2,481 \\
\hline
\end{tabular}

Note: Standard errors in parentheses corrected for spatial/temporal correlations.

* p-value $<0.10 ; * *$-value $<0.05$.

a Seawater temperature values imputed for Mar 2012 to Dec 2013.

b Bayesian Information Criterion (BIC) is a statistical measure of model fit.

Parameter estimates are highly consistent across models. Results in Tables 8-10 show that feed use and seawater temperatures have a positive effect on monthly fish biomass growth, while average fish size has a negative effect. Specifically, focusing on the Fixed Effects [1] results in Table 10, an additional 100 tonnes of feed in the current month, holding all else constant, will increase the rate of biomass growth by $2.20 \%$; an increase in the previous month's average seawater temperature by $1^{\circ} \mathrm{C}$, holding all else constant, will increase the rate of growth by $0.87 \%$; and a $1 \mathrm{~kg}$ increase in the previous month's average fish size, holding all else constant, will decrease the rate of growth by $6.33 \%$.

With respect to the main question of interest, each model reports no statistically significant impact of ammonium nitrogen, nitrate, or total nitrogen levels on fish biomass growth in other words, ${ }^{5}$ our results suggest that higher levels of ammonium nitrogen,

${ }^{5}$ An alternative specification replacing seawater temperature with monthly dummies (May 2010-Dec 2013) reports similar estimates as specification [2] for each model, finding no statistically significant impact of ammonium nitrogen, nitrate, or total nitrogen on fish biomass growth. Similarly, an alternative specification that includes all three nitrogen reports in the same model finds no significant impacts while yielding similar parameter estimates for the other independent variables. 
nitrate, or total nitrogen measured at the nearest nutrient monitoring station in the previous month, holding all else constant, has no significant effect on a farm's rate of salmonid biomass growth. Specifically, results in Tables 8-10 show that parameter estimates for ammonium nitrogen, nitrate, and total nitrogen respectively are not insignificant at any reasonable level of statistical confidence. ${ }^{6}$

\subsection{Conclusions}

Hypoxia due to nitrogen discharges has a substantial potential to reduce productivity at a salmon farm, as has algae blooms caused by nitrogen discharges. Indeed, these were serious challenges in Norwegian salmon farming in the 1990 (Johnsen and Sakshaug, 2000). However, salmon farmers have strong incentives to alter production practices to avoid or mitigate the consequences of such productivity reducing phenomenon. They also have a strong track record in solving or addressing issues that influence productivity. Tveterås (2002) suggests that the most important environmental challenges that the industry faced followed an Environmental Kuznets Curve pattern. Here, the problem increase as the industry start to grow, but as the problem is understood and knowledge increase, the problem is addressed and often disappears. Tveteras (2002) shows this for use of antibiotics and chemicals.

The fact that hypoxia and algae received much more attention at the turn of the century, as exemplified by Johnsen and Sakshaug (2000), than more recently can be interpreted as evidence that these problems to a large extent has been addressed. Our empirical results support such a conclusion, as we find no evidence that nitrogen levels influence fish growth in the Bokna Fiord despite the fact that this was one of the areas were the challenges associated with hypoxia and algae blooms were largest in the 1990 .

${ }^{6} \mathrm{p}$-values range from 0.365 to 0.367 for ammonium nitrogen; 0.343 to 0.388 for nitrate; and 0.626 to 0.629 for total nitrogen. 



\section{Perspectives on importance of nitrogen for Nordic fisheries and aquaculture}

\subsection{Introduction}

Based on the analyses of the Socio-economic importance of nitrogen nutrient load in the environment for Nordic fisheries and aquaculture performed in chapter 2 and 3, the purpose of this chapter is to provide broader perspectives on the importance of nitrogen for Nordic fisheries and aquaculture. These perspectives were provided by organizing a workshop, funded by the Nordic Council of Ministers, with participation from Denmark, Finland, Sweden and Norway and with participation from the industry, officials from fisheries and environmental authorities and researchers. The title of the workshop was Fisheries, aquaculture and the marine environment: Environmental challenges and regulation, with focus on nitrogen. It was held at Radisson Blu Falconer Hotel \& Conference Center, Copenhagen in June 2015. The conference was organized by University of Copenhagen, University of Stavanger and AfriFood Economics Centre/SLU, Lund. The conference lasted for $1 \frac{1 / 2}{2}$ day. The program is available in appendix $C$, a list of participants in appendix D and presentations are available at: http://ifro.ku.dk/english/research/sections/environment/agfiskworkshop/

\subsection{Purpose}

The purpose of the workshop was to improve knowledge on the importance of nitrogen and nutrients for sustainable growth in fisheries and aquaculture in the Nordic countries. Focus was at revealing existing knowledge on the role of nitrogen in relation to the economics of fisheries and aquaculture, and on how the two sectors contributes most to the socio-economy within the current total nitrogen discharge level. Furthermore, the focus was at how to approach nitrogen discharges through direct management and through development of alternatives and supplements to management, such 
as mussel farming and removing nutrients in fish caught. A summary of each presentation is provided in the next section, after which a perspectivation of the inputs are made by the authors. The last section draws the overall conclusions.

\subsection{Summary of presentations}

\section{Jette Bredahl Jacobsen (JBJ), University of Copenhagen: Economics of the Ecosystem Service approach to Management: Forest Experience}

The presentation by JBJ was an introduction to the "Ecosystem Service Approach" related to forest management. The possibility of transferring experience and knowledge from forest management by the "Ecosystem Service Approach" to marine management was discussed and potential similarities or critical differences related to valuation, biodiversity and ecosystem services were presented. The diversity of services supplied by a given ecosystem makes it highly complex to define and capture all its functions and services, which is a necessary step in the process of estimating the value of the ecosystem. Both "Use Value" and "Non-use Value" must be included in the calculations. A commonly used approach in forest valuation is a willingness to pay analysis. Through interviews or questionnaires peoples willingness to pay for a given ecosystem service is identified. Results from such an analysis, concerning endangered species' survival, were presented and JBJ concluded that society has a genuine interest in biodiversity. However determining the appropriate and desired level of biodiversity is difficult and the next question that arises is; who should then pay for the costs associated with maintaining of creating more biodiversity? Neither one is easy to answer. Through her presentation JBJ drew attention to the fact that taxonomy for nature resources is urgently needed in order to prevent misuse or unfortunate use of nature resources.

\section{Anders Kiessling (AK), Swedish University of Agricultural Sciences: Visions for Aquaculture in Sweden and the Baltic Sea Area}

The presentation by AK was an outlook on the future visions and possibilities for aquaculture in Sweden and the Baltic Sea area. Aquaculture is becoming increasingly important as it is providing a greater and greater share of total fish production and is expected to be vital for future food security. Since 2000 aquaculture production globally has increased by $6.9 \%$ but when looking at the European Union aquaculture production has in the same period only grown by $0.5 \%$. This slow growth has happened despite a political desire of an annual growth rate of $4 \%$. Comparing all animal meat productions, 
fish is the most efficient protein transformer and is, with the increasing demand, becoming a very important source of protein. The growing fish consumption and production is expected to continue and AK argued that this expansion of production may occur along two lines; through ocean based open cage systems and through closed or semiclosed systems. Especially inland aquaculture is according to the FAO "State of the worlds' fisheries and aquaculture 2014 " expected to be an important factor to obtain future food and nutrition security. AK pointed out that this intensification and increased production of aquaculture is limited by the requirement that it has to be sustainable both considering ecological, social and economic factors. One way to improve the environmental impacts of aquaculture is by using bio-protein in the fish production. The idea of transforming food, plant and animal waste into bio-protein and using it as fish feed, as suggested by the Swedish company Micrpos, won the Swedish Green Innovation price in 2012. Green Water Farming was also introduced as another type of production system within aquaculture. This system incorporates surplus energy into its production and uses this to heat the water, which is found to have a positive impact on the growth rates for salmon.

\section{Teis Boderskov (TB), Hjarnø Havbrug, Nutrient Compensation: Endelave Fish Farm on condition of nutrient removal}

TB presented the case of Endelave Havbrug A/S, which is a fish farm company located in Eastern Jutland. Endelave Havbrug A/S has a long tradition for mariculture fish production going all the way back to 1952. Today the company employs 25 fulltime workers and 50 seasonal workers and is administering maricultures fish productions, mussel production and ecological certified seaweed production all located in Horsens Fiord. Their main species is rainbow trout, including both large and small trout roe. The fish are sold in Denmark, countries within the EU, and are also shipped to Japan, Russia (when applicable) and other countries outside the EU. Endelave Havbrug was granted a new farming licence in 2014 on the condition of $100 \%$ nitrogen compensation. The nitrogen compensation was to be achieved by producing mussels and seaweed close to the mariculture production. Mussels and seaweed would extract nutrients from the water, and when the mussels and seaweed were harvested, the nitrogen is removed from the sea. This system of production, where the by-product from one species is used to feed another species, is a form of integrated multi-trophic aquaculture (IMTA). It help balance the marine ecosystem. In the case of Hjarnø Havbrug, seaweed and mussels located close to the mariculture production extracted the uneaten feed and nitrogen compensation was thereby achieved. Besides being a compensation tool the produc- 
tion of mussels and seaweed also contributed as a harvestable crop and yield. The technique, expected yield, challenges and opportunities for both mussel and seaweed production were described through the presentation. Hjarnø Havbrug had invested a substantial amount and energy in extending their fish farm by simultaneously developing compensation farming of seaweed and mussels. TB considered this investment a success. However, the new license were withdrawn due to an decree from the Board of Nature and Environmental Complaints stating that seaweed and mussels cultivation did not any longer qualify for a compensation tool, implying that Endelave fish farming's application for an environmental impact assessment was denied on the 23th of December 2014. Hence, despite the investments and success, Endelave Havbrug has stopped their new activity.

\section{Jacob Hagberg (JH), Swedish Ministry of the Environment: Status and regulation of the marine environment in the Baltic Sea}

$\mathrm{JH}$ gave an overview of the status and regulation of the marine environment of the Baltic Sea from a policy perspective, focusing at current knowledge and knowledge needed as a basis for ecosystem based management. He presented maps of the status of the marine environment in relation to eutrophication, hypoxia and anoxic bottom waters in the Baltic Sea, particularly focusing at the severe situation south of the Gulf of Bothnia to the inner Danish waters. He continued by providing a stock status for the main species, with both the East and West Baltic cod stocks being at low levels, but recovering the last 2-3 years. The herring and sprat stocks are in better condition, with herring increasing and sprat decreasing. $\mathrm{JH}$ also noted that the stock of stickleback has increased dramatically in recent years, thereby acknowledging the need for multispecies management. Management targets relevant in an ecosystem based management approach were mentioned, focusing at reducing eutrophication by reducing N/P discharges, at reducing fishing mortalities to below the MSY level and at improving coastal areas through addressing species interaction, obtaining clearer water and more macroalgae. $\mathrm{JH}$ further underlined the need for a holistic approach covering all marine activities and all countries surrounding the Baltic Sea. He demonstrated the complex interactions in the coastal areas of ecosystems, ecosystem functions and ecosystem services showing results that indicate how fisheries management will have implications for eutrophication symptoms such as water clarity, algal blooms and epiphytes and vice versa. He concluded that the results imply that all parts of marine management need to work towards the same targets and be integrated in management advice. 


\section{Kristin H. Roll (KHR) University of Stavanger: The Economics of Escaped Farmed Salmon}

The development within the Norwegian salmon industry with a focus on the economic perspective of escaped salmons from aquaculture was examined in this presentation. Yield, production, price, environmental impacts and new technologies were considered and described. For salmon aquaculture, innovation and rapid technological progress have not only led to an increased productivity, but also to an overall larger production and reduced marginal costs. The implication of larger and more intensive production has also led to greater environmental impacts and side effects from production. That implies that the aquaculture industry is now facing environmental challenges. Sedimentation under the cages, nutrition discharges from fish farms, escapes, disease outbreaks and leakage of antibiotics are all issues related to aquaculture production that needs to be considered. In the presentation environmental challenges were separated into two categories. The main and crucial difference separating the two categories is determined by whether or not the environmental impacts impose costs on the fish farm or on society. If the costs of the fish farms are affected by the environmental impact, the fish farm has an economic incentive to solve the environmental problem itself. However, if the opposite is true and the environmental impact appears as a negative externality harming society but not affecting the fish farm, then the firm has no economic interest in solving the problem. An analysis was presented focusing on the escapees from aquaculture and it was concluded that escapees do neither directly nor indirectly affect the farmers' cost of production. The implication of this finding is that if a lower level of escapees is desired, society has to lead the way due to the lack of financial incentive amongst fish farms.

\section{Lars Ravn-Jonsen (LJR), University of Southern Denmark: Bio-economic model of Eastern Baltic cod under the influence of nutrient enrichment}

LJR motivated his topic and presentation by describing how the East Baltic cod stock has shown a declining trend since the early 1900 s. The cod was at a point of extinction and political interference has been applied to stop the declining fish stock. This critical state of the cod stock is assumed to be a consequence of intensive fishing but also nutrient enrichment, which has led to oxygen depletion and eutrophication in areas where the cod reproduce. The Helsinki Commission (HELCOM) has both in 1988 and later in 2009 implemented and adopted ministerial declarations aiming to reduce nutrient inputs to the Baltic Sea. LRJ examined the essential question on how to shape an efficient and economic optimal fisheries policy in the Eastern Baltic Sea when fish stocks are under influence of nutrient concentrations. LRJ depart from a dynamic bio- 
economic model of fisheries identifying the optimal fleet size and extended it to also take the effect of nutrient enrichment on the Eastern Baltic cod stock into account. The analysis showed that the effect of a reduction in nutrients on the economics of the fishing vessels (the net present value) is very small. Instead there are substantial gains from reducing the fishing fleet to the economic optimal fleet size, which is below the MSY level and considerable below the current fleet size level. Hence, the analysis conclude that overfishing is of severe importance for the poor state of the Eastern Baltic cod stock and for the poor economy of the fishing vessels, but also that nutrient enrichment is of little importance for the size of the eastern Baltic cod stock and for the economy of fishermen.

\section{Cecilia Hammerslund (CH), AgriFood Economics Centre/SLU, and Max Nielsen $(M N)$, University of Copenhagen, Management and Economics of Cod Fisheries in the Western part of the Baltic Sea and Nitrogen Discharges}

This presentation consisted mainly of an analysis of the socio-economic effects on the Danish and Swedish fishing fleet when reducing the level of nutrients and/or changing the fisheries policy in the Western part of the Baltic Sea. The analysis was carried out using a static bio-economic model, which describe cod harvest as a function of the cod stock, the fishing effort and the nitrogen concentration in the sea. The concentration of nitrogen and the level of eutrophication in the sea is currently a main focus for the environmental policies through the water framework directive. In a period from 19401980 the correlation between the level of nitrogen concentration and the size of the cod stock was proven positive. At the time, adding nutrients had a positive impact on the size of the fish stock, but since the 1980s, nitrogen discharges has been considered deeply problematic from an environmental point of view. The result is a strict environmental policy with limitations on discharges of nitrogen and nutrients into the Baltic Sea in most countries surrounding the Baltic Sea. The latest development has been a decrease in the inflow of nitrogen and phosphor to the Baltic Sea, but the concentration of nutrients has not decreased proportionally. Algal biomass is not decreasing and more bottom areas without oxygen have appeared. Since low levels of oxygen at the sea bottom are critical for the cod's possibilities for reproduction, this development is unfortunate. $\mathrm{CH}$ and $\mathrm{MN}$ departed from a static bio-economic model of fisheries to identify the socio-economic optimal fleet size for cod in the Western part of the Baltic Sea. This model is extended with impact on fish stocks and fisheries from nitrogen concentrations, claiming that increasing nitrogen discharges, all other things equal, leads to improved cod catches in the long run until the optimal pollution effect is reached. Higher 
nitrogen concentrations will then reduce the cod stock, due to oxygen depletion, hypoxia and eutrophication. It was concluded that the West Baltic cod stock is close to the socio-economic optimal level of nitrogen concentration, all other things equal, implying that the cod stock may be reduced in the long run, both if nitrogen concentration increase and decrease. This reduction was, however, found small. It was further concluded that large gains in the socio-economic contribution could be achieved both for Danish and Swedish fishermen active in the West Baltic cod fishery by reducing the fleet size to below half the current level. As the former presenter, $\mathrm{CH}$ and $\mathrm{MN}$ found that the socio-economic contribution of cod fisheries in the Baltic Sea will improve substantially with a policy of fleet reduction, but that nitrogen is not very important for the socioeconomic contribution of fisheries.

\section{Jarno Virtanen (JV), Natural Resource Institute Finland, The Value of Environmental Impact of Fisheries on Nutrient Dynamics: Case of Finnish Pelagic Trawling}

JV presented a case study of the Finnish pelagic trawling and the positive impacts on the nutrient dynamics of this industry in the Baltic Sea, with the positive impact coming from the removal of nutrients in the fish caught. Firstly, JV described the currently environmental state of the Baltic Sea followed by an analysis of the fisheries' impact on nutrient dynamics. Lastly, JV presented an estimation of the value of the fisheries and the positive impact. The Baltic Sea is one of the most polluted seas in the world and due to its nature as a common pool resource the lack of property rights makes it vulnerable for misuse and overexploitation. The "Helsinki Convention" and later the "Baltic Sea Action Plan" were both implemented to obtain a better marine environment. Challenges for the marine environment, JV explained, originates from discharges from ships, hazardous substances and most importantly nutrients such as phosphor and nitrogen, potentially inducing eutrophication, which is caused by human activities from agriculture, industries and forestry etc. Nutrients are causing changes to the marine ecosystems, as increased growth of phytoplankton, increased algae blossom and oxygen depletion amongst other negatively impacts the environment. Countries along the Baltic Sea have therefore committed to reduce phosphor and nitrogen. The concrete nutrient reduction targets were presented and this fishery, as well as other fisheries, is important as a source for reduction of nutrients from the sea. The removal of nutrients from the marine areas thus forms a positive externality of the fishery. The implication is that in the case of a reduction in fishing activity, a compensating measure would be required to replace the fishery's function as a nutrient reducer. If the positive externality is included in calculations and given to the fishermen, 
the pelagic Finnish fishery becomes very profitable especially when the fleet size simultaneously is reduced to the optimal level. One instrument to achieve the socio-economic optimal situation is to allow polluters to pollute more, if they pay fishermen for removing the same amount of nutrients.

\section{Rasmus Nielsen (RN), University of Copenhagen, Importance of Nitrogen for} Aquaculture growth in Denmark

Throughout the presentation by RN, Danish aquaculture's potential for sustainable growth was discussed. A main challenge for increased production is the environmental restriction and targets, which Denmark has agreed to. Growth has to happen within the framework and limits set up in the environmental policies. As many other countries Denmark has committed to a reduction in the use of nitrogen and phosphor in its aquaculture production as well as in other sectors. Nitrogen is considered the most important pollutant potentially leading to oxygen depletion, hypoxia and eutrophication, which are all unfortunate outcomes for the environment. RN mentioned several aspects of production, which could be considered and developed and being key factors for the future growth of aquaculture. Amongst these are feeding, breeding, technology, economies of scale etc. Another aspect is integrated multi-trophic aquaculture where biproducts and waste from one production becomes an input in another. RN mentioned how production of mussels and seaweed can be feed with surplus feed from fish farming and thus at the same time contribute as a tool of nutrient compensation. In his conclusion RN stated that growth can be achieved without increasing emissions of nitrogen. Changing the regulatory system by making emission quotas tradable would have a significant positive effect on production for aquaculture. Changes in the bureaucracy climate, better communication between relevant authorities and availability of new licenses are all necessities if the potential for sustainable growth in the future is to be exploited and make introduction of new technology profitable.

\section{Jari Setälä (JS), Natural Resources Institute Finland, Marine Fish Farming and Nitrogen in Finland}

Several aspects related to fish farming in Finland was introduced by JS. Fish farming is mainly located in the South-Western part of Finland. Considering both value and quantity salmon trout is the fish species produced most. Through the 1980s the Baltic Sea experienced a rapid eutrophication resulting in restrictions on production as well as making it harder to obtain an aquaculture license. At the same time the level of international competition increased and oversupply of salmon at the world market led to 
reduced prices of salmon trout also domestically in Finland. The combination of lower prices and stricter environmental management have made the conditions for production harder for Finnish fish farmers, inducing stagnation for the sector ever since. One solution concerning the environmental challenges of Finnish aquaculture, JS pointed out, has been a change in the fish feed used, since alternative sources of fish feed has made it possible to reduce both phosphor and nitrogen loading from aquaculture production. Besides benefitting the environment, aquaculture also profits from higher level of feed efficiency. Another way to protect the environment and enable aquaculture production growth in Finland is to introduce recirculated systems. Open-sea marine fish farming and recirculation systems in the inland areas are the main means to enforce the $2020 \mathrm{EU}$ Aquaculture Strategy for Finland, where the goal is to secure a sustainable production growth.

\section{Frank Asche (FA), University of Stavanger: Externalities, Nitrogen Discharges and Marine Aquaculture}

This presentation by FA firstly illustrated how aquaculture production of salmon in Norway have increased from 1985 and onwards just as productivity within the industry has advanced. Simultaneously, costs of production and the price of salmon have experienced a large decrease in the same period. The overall increase in aquaculture production has brought with it new environmental challenges and concerns for the local environment. Nutrient loadings are among these environmental worries. Despite the fact that less than $3 \%$ of nutrient loading in Norway is caused by human activity it is a political target to reduce the nutrient leakages from production, including production in aquaculture. High nitrogen loadings do not constitute any large-scale system challenges, according to FA, but in warm summers when causing hypoxia it becomes a local problem and concern. Larger and deeper pens have partly been a solution to this problem. Based on a model analysis FA conclude that hypoxia at times is an issue in salmon farming and another important finding was that no relation between nitrogen loadings and salmon growth rates was found in the analysis focussing at the Bokna Fiord in Southern Norway. This conclusion implicates that no economic incentive exists for Norwegian aquaculture to reduce nitrogen discharges other than if the sector is claimed to do so by management introduced politically. In the last part of the presentation, a comparison of the carbon footprint for the production of fish, chicken, beef or pork meat was made. Production of fish performs best compared to the other protein sourcs when considering performance in relation to several environmental parameters as edible yield, protein retention and carbon footprint. On this basis, FA point out that fish production is highly competitive environmentally, compared to the other meat productions. 


\section{Mogens Schou (MS), AQUAMIND, How to transform public management?}

MS emphasized natural capital's importance for humankind's survival in his presentation. Natural capital differs in many ways from monetary capital with a main difference related to the valuation. Unlike monetary capital, natural capital is not valuated, which is often seen to lead to misuse and misallocation along with an exposure of negative externalities to society. Defining natural capital, MS stated, is rather difficult but there is nevertheless an urgent need to somehow develop taxonomies in order to better understand, value and manage natural capital. This is essential to secure a proper use and MS gave three main reasons for putting a value on natural capital; Inclusion of externalities, incentivizing innovation and best practices, and synergizing complementary productions. MS further states that a change in policy climate is required, since today's policy is focussed on using command and control instruments and, simultaneously, fight activities involving use of natural capital. As alternative to command and control instruments, MS suggests a strategy based on incentives in the form of result based management of natural capital. MS believe that giving firms free choice of method and technology and possibility for trading quotas will result in optimization of every single unit of natural capital applied or used in production. Because the aquaculture industry will act innovatively towards boundaries and limitations, the result of this policy will be improved fish production, increased welfare in society and reduced use of natural capital. Political focus and leadership and a new understanding in the central administration are key aspects if a proper use of natural capital is to be obtained in the future, MS finished.

\subsection{Perspectivation of workshop discussions}

Approaches to management of the marine environment were discussed, including the ecosystem approach and the natural capital approach. As the basis of management, knowledge on valuation of marine ecosystem services is needed to counterbalance the costs and benefits of changing environmental management. The discussion departed from valuations made for forest ecosystems identifying peoples' willingness to pay for better environment and translating this into a marine ecosystem setup. The concept of natural capital, considering natural resources measurable in monetary terms, was also mentioned as an important framework for understanding, valuating and managing marine areas. The needs for applying the ecosystem approach to marine management were underlined by several and, to make that work, the need for taxonomies of natural marine resources were specified. 
On the basis of the discussion of approaches to broader marine management, the workshop narrowed the scope to look into the importance of nitrogen for Nordic fisheries and aquaculture. Several issues (market failures) related to the efficiency of management of nitrogen in the marine environment, that claim management in order to be handled properly from a society perspective, were raised as relevant for fisheries and aquaculture at the workshop. These are:

- Discharges of nitrogen and phosphor from fish farms (both land-based and marine) inducing negative environmental effects and affects the growth rates in nearby fish farms.

- Nitrogen and phosphor uptake in farmed mussels and seaweed inducing positive environmental (cleaning) effect.

- Effects of nutrient concentrations in marine areas on fish stock productivity and the economics of fisheries, which are positive at small concentrations with an increased feed basis, but negative at high concentrations with oxygen depletion, hypoxia and eutrophication.

- Nitrogen and phosphor removal in fish caught by fishing inducing a positive environmental effect.

- The effect of bottom trawling on visibility in waters, where bottom trawling might amplify and spread the effect of nutrients depositions at the sea floor and thereby potentially induce the negative environmental effect.

Escapements from marine fish farms were also discussed.

The importance of these potential problems for Nordic fisheries and aquaculture was discussed. The discussion revealed that although fisheries are affected by the high concentrations of nutrients, the current level in the Baltic Sea is close to the optimal level. Therefore, the socio-economic contribution of fisheries will not increase from reduced discharges of nutrients (nor from increased discharges). Hence, the socio-economic contribution of fisheries can only be improved using traditional fisheries management instruments to "avoid that there are too many fishermen to fish too few fish". Moreover, reducing the level of nutrient concentrations in the Baltic Sea substantially, in order to fulfil the objectives of the environmental policy, is expected to have negative consequences for the socio-economic contribution of fisheries, since it can reduce the feed base for the main cod stocks.

The discussion of the importance of nitrogen for aquaculture revealed that in the case of Norway, despite that nutrient discharges are among the potential environmental concerns and causes hypoxia in warm summers, it seems not to constitute any large- 
scale system challenges. Occasionally, however, it becomes a local concern e.g. in Bokna Fiord. The situation in aquaculture in the Baltic Sea, however, differs substantially with the main barrier for sustainable growth being the environmental management of nutrients, in particular nitrogen. This is the case for both Denmark, Finland and Sweden. There, aquaculture growth is limited by nitrogen management, although it was mentioned that it is possible to achieve sustainable growth, within the current level of emissions, by implementing more efficient management in the form of tradable nitrogen emission quotas.

One option of reducing nutrient concentrations is to limit discharges through the environmental management, where the overwhelming majority comes from land based activities such as agriculture. The discussion did, however, also reveal that an alternative and supplement to this is to clean waters by removing nutrients. It was in the case of Finland shown that phosphor and nitrogen was removed with fish caught, since the fish have an uptake of nutrients. Furthermore, farmed mussels and seaweed also have an uptake of nutrients that are removed from the sea when harvested. Thereby, farming of mussels and seaweed become an environmental policy instrument that is integrated in current environmental management in some of the Nordic countries. In Denmark it is claimed to have a new licence for marine fish farming, that the company removes the same amount of nutrients using compensation farming of mussels and seaweed. The Danish company Hjarnø Havbrug presented their successful experience in this after having received a licence for extended marine trout farming claiming compensation farming and therefore investing in the extended activity. However, shortly after their start the license was withdrawn due to an order from the Board of Nature and Environmental Complaints stating that seaweed and mussel cultivation did not any longer qualify as a compensation tool.

Another alternative to improve the environmental impacts of aquaculture was the use of bio-protein. Moreover, today the expansion of aquaculture occurs along two lines; through ocean based open cage systems and through closed or semi-closed systems. Since closed aquaculture systems decouple fish production from the surrounding environment, nitrogen discharges does not go into marine waters and appears as an option of growth in aquaculture, without nitrogen discharges. Fully recirculated systems are in use, although their long-run economic feasibility remains to be proven. 


\subsection{Conclusions}

It was concluded by some participant that the main challenge of nitrogen for fisheries and aquaculture in the Nordic region relates to nitrogen management of aquaculture in the Baltic Sea. Some of these called for more efficient management of the current total discharge level of nitrogen. Such management was believed to be able to induce growth in aquaculture in the Baltic Sea area. Other participants underlined that the current legal framework for the environment does not provide any options and flexibility of making such a development possible. This discussion departed from the situation in Denmark, but it was mentioned that it is exactly the same situation in Finland.

Focussing at the Baltic Sea, nitrogen was considered less important for fisheries, since we today are relative close to the optimal level of nitrogen concentration for the Baltic cod stocks. The main challenge might come from a possible substantial future reduction in total discharges that affect the feed basis for fisheries in the Baltic Sea negatively. But that has to be shown. 



\section{Conclusions}

In this report, the Socio-economic importance of nitrogen nutrient load in the environment for Nordic fisheries and aquaculture was analyzed and discussed. The management perspectives of the interactions between fisheries and aquaculture on the one hand, and the environment on the other, were also discussed. It was found that nitrogen and nitrogen management is important in the Baltic Sea, but no indications of substantial problems were identified elsewhere in the Nordic area. The interaction between fisheries and aquaculture on the one hand, and nitrogen management on the other, appear mainly of importance in the East Nordic area in Denmark, Finland and Sweden. The report further points towards the option to develop cleaning actions in the form of removal of nutrients in fish caught and by breeding mussels and seaweed.

In the first case study of cod fishery in the Western part of the Baltic Sea a bio-economic model were extended to analyze the effect of nitrogen on the cod stock and the socio-economics of fisheries. The model departed from the idea that growth in biomass increases with increasing availability of nutrients, owing to a larger feed base up to a peak, after which growth falls due to eutrophication. The model identified the socioeconomic contribution of fisheries under the influence of nitrogen. In 2010, the socioeconomic contribution was $-28 \%$ of the landing value. Maximizing the model with respect to fishing effort alone and additionally over nitrogen concentration increases the contribution to $11 \%$. To achieve this, the fleet must be reduced from 81 vessels to 24 vessels and slightly less when considering nutrients. The initial negative socio-economic contribution indicates that labor and capital used in the fleet segments have larger value when used in other sectors. The analysis showed that the socio-economic effect of reducing fishing effort through management reforms is large, but that the effect of incorporating nitrogen in fisheries policy is small, even in an area with one of the highest concentrations of nutrients worldwide; the Baltic Sea.

The second case study on salmon farming in the Bokna Fiord, was founded in production economics and estimated how different levels of nitrogen concentrations affect the growth rate of salmon. Detailed regression analyses were performed without being able to identify any interaction between nutrient concentrations in the water and growth rates of salmon. The reason for this result remain a matter of speculation, but it is assessed that it is due to the fact less than $3 \%$ of the nutrient load in Norway originates from human activities, as compared to $82 \%$ in Denmark. Despite that a political 
purpose in Norway is to reduce nutrient discharges, the conclusions is that it cannot be rejected that high nutrient concentrations does not form a large problem for Norwegian salmon aquaculture. In warm summers, however, oxygen depletion is occasionally a local problem.

Based on the two case studies and inputs from several invited speakers, the broader perspectives on the Socio-economic importance of nitrogen nutrient load in the environment for Nordic fisheries and aquaculture were discussed at a workshop. The discussion revealed that although fisheries are affected by the high concentrations of nutrients, reducing nutrient discharges is not expected to induce a large effect on the socio-economic contribution of cod fisheries. This accounts for fisheries of both the East and West Baltic cod stock. Hence, the socio-economic contribution of fisheries can only be improved through the use of traditional fisheries management instruments such as individual transferable quotas to avoid that too many fishermen catch too few fish.

The discussion of the importance of nitrogen for aquaculture revealed that in the case of Norway, despite that nutrient discharges are among the potential environmental concerns and cause hypoxia in warm summers, it seems not to constitute a largescale challenge to the ecosystems and the ecosystem services. However, the situation in the Baltic Sea differs substantially with the main barrier for sustainable growth in aqvaculture being the environmental management of nutrients, in particular nitrogen. This is the case for Denmark, Sweden and Finland. In these countries aquaculture growth is limited by nitrogen and phosphor management. However, some participants underlined that it is possible to achieve sustainable growth, within the current level of nutrient emissions, by implementing more efficient management in the form of tradable emission quotas.

One option of reducing nutrient concentrations is to limit discharges through environmental managements, where the overwhelming majority comes from land based activities such as agriculture. The discussion at the workshop did, however, also reveal that an alternative/supplement to this is to clean waters by removing nutrients. In Finland it was shown that phosphor and nitrogen were removed by fish caught, since the fish have an uptake of nutrients. Furthermore, farmed mussels and seaweed also remove nutrients from the sea when harvested. Hence, farming of mussels and seaweed become an environmental policy instrument, which is integrated in the current environmental management in some of the Nordic countries.

It was generally concluded by some participant at the workshop that the main challenge of nitrogen for fisheries and aquaculture in the Nordic region relates to nitrogen management of aquaculture in the Baltic Sea. These participants called for more efficient management, within the current total discharge level, which was believed to be able to induce growth in aquaculture in the Baltic Sea. Other participants underlined 
that the current legal framework for the environment does not provide any options and flexibility of making such a development possible. This discussion was considered of particular importance in Denmark, but it was mentioned that the situation was exactly the same in Finland and Sweden.

Focussing at the Baltic Sea, nitrogen was considered less important for fisheries, since we today are relative close to the socio-economic optimal level of nitrogen for catches from the Baltic cod stocks. The main challenge might rather come from a possibly substantial future reduction in total discharges that might affect the feed basis for the cod stocks in the Baltic Sea negatively. But that has to be seen.

Based on the two case studies and input at the workshop, conclusions of relevance for the policy issues of today was summarized to that:

- There are no indications that the socio-economic contribution of Danish and Swedish cod fisheries in the Western part of the Baltic Sea will be considerably affected by changed nitrogen concentration in the Baltic Sea.

- There are no indications that the profitability of the Norwegian salmon farming are considerably affected by nutrients.

- The socio-economic contribution of fisheries in the Western part of the Baltic Sea is expected to improve when the structural adjustment following individual transferable quotas gradually continues in Denmark and if introduced in Sweden.

- Management of nitrogen is the crucial barrier for sustainable growth of aquaculture in the Baltic Sea.

- Nutrients and nitrogen management is of large importance to aquaculture in the Baltic Sea, but there are indications that it is of little importance to fisheries in the Baltic Sea and that it is of very limited importance for fisheries and aquaculture in the remaining Nordic region. 



\section{References}

Aasheim, L. J., R.E., Dahl, S.C. Kumbhakar, A. Oglend \& R. Tveterås (2011) Are prices or biology driving the short-term supply of farmed salmon? Marine Resource Economics, 26, 343-357. https://doi.org/10.5950/0738-1360-26.4.343

Abolofia, J. N. (2014) The Bioeconomics of a Common Property Pest: Parasitic Sea Lice and Farmed Salmonids. PhD dissertation, University of California, Davis, 2014.

Abolofia, J. N., F. Asche, J.E. Wilen (2014) "Putting a Price on Lice: Quantifying the Impacts of Sea Lice on Farmed Salmonids", unpublished manuscript.

Andersen, T.B., K.H. Roll \& S. Tveterås (2008) The price responsiveness of salmon supply in the short and long run. Marine Resource Economics, 23, 425-438.

https://doi.org/10.1086/mre.23.4.42629673

Anderson, L.G. (1975), Analysis of open-access commercial exploitation and maximum economic yield in biologically and technologically interdependent fisheries. Journal of the Fisheries Research Board of Canada 32:1825-42. https://doi.org/10.1139/f75-217

aquaculture. Aquaculture Economics \& Management, 15(4), 262-277.

Asche, F. \& K.H. Roll 2013. Determinants of inefficiency in Norwegian salmon aquaculture. Aqvaculture Economics and Management, 17, 300-321.

https://doi.org/10.1080/13657305.2013.812154

Asche, F. and Bjørndal, T. 2011. The Economics of Salmon Aquaculture, Wiley-Blackwell: Chichester.

Asche, F., 1997. Trade disputes and productivity gains: the curse of farmed salmon production? Marine Resource Economics 12, 67-73. https://doi.org/10.1086/mre.12.1.42629183

Asche, F., A. G. Guttormsen and R. Nielsen (2013) Future Challenges for the Maturing Norwegian Salmon Aquaculture Industry: An analysis of Total Factor Productivity Change from 1996 to 2008. Aquaculture. 396-399, 43-50. https://doi.org/10.1016/j.aquaculture.2013.02.015

Asche, F., A. G. Guttormsen, and R. Tveterås (1999) "Environmental Problems, Productivity and Innovations in Norwegian Salmon Aquaculture". Aquacultural Economics and Management, 3, 19-30. https://doi.org/10.1080/13657309909380230

Asche, F., and Guttormsen, A.G. 2001. Patterns in the Relative Price for Different Sizes of Farmed Fish. Marine Resource Economics 16(3): 235-247.

https://doi.org/10.1086/mre.16.3.42629321

Asche, F., K. H. Roll, H. N. Sandvold, A. Sørvig and D. Zhang (2013) Salmon Aquaculture: Larger Companies and Increased Production. Aquaculture Economics and Management. 17(3): 322-339. https://doi.org/10.1080/13657305.2013.812156

Baden, S.P., L.-O., Loo, L., Pihl, Rosenberg, R. (1990), Effects of eutrophication on benthic communities including fish: Swedish west coast. Ambio 19: 113-122.

Barbier, E.B. and I. Strand (1998), Valuing mangrove-fishery linkages. Environmental and Resource Economics, 12: pp. 151-166. https://doi.org/10.1023/A:1008248003520 
Bjørndal, T. (1988). Optimal Harvesting of Farmed Fish. Marine Resource Economics, 5(2), 139-159. https://doi.org/10.1086/mre.5.2.42628926

Breitburg, D.L. (2002), Effects of hypoxia, and the balance between hypoxia and enrichment, on coastal fishes and fisheries. Estuaries 25: 767-781. https://doi.org/10.1007/BF02804904

Breitburg, D.L., J.K. Craig, R.S. Fulfor, K.A. Rose, W.R. Boynton, D.C. Brady, B.J. Ciotti, R.J.Diaz, K.D. Friedland, J.D. Hagy III, D.R. Hart, A.H. Hines, E.D. Houde, S.E. Kolesa, S.W. Nixon, J.A. Rice, D.H. Secor, T.E. Targett (2009), Nutrient enrichment and fisheries exploitation: Interactive effects on estuarine living resources and their management. Hydrobiologia 629: 31-47. https://doi.org/10.1007/s10750-009-9762-4

Claireaux G. and J. Dutil (1992), Physiological response of the Atlantic cod (Gadus morhua) to hypoxia at various environmental salinities. J. Exp. Biol. 118: 97-118.

Clark, C.W. (2005), Mathematical Bioeconomics: Optimal Management of Renewable Resources, Second Edition, Wiley Interscience, New Jersey, USA.

Copes, P. (1972), Factor rents, sole ownership and the optimum level of fisheries exploitation. The Manchester School of Social and Economic Studies 40:145-63.

https://doi.org/10.1111/j.1467-9957.1972.tbo1106.x

Dalgaard, T., B. Hansen, B. Hasler, O. Hertel, N. J Hutchings, B.H. Jacobsen, L.S.B. Kronvang, J.E Olesen, J.K Schjørring, I.S. Kristensen, M. Graversgaard, M. Termansen, H. Vejre (2014), Policies for agricultural nitrogen management - trends, challenges and prospects for improved efficiency in Denmark. Journal of Environmental Research Letters 9, https://doi.org/10.1088/1748-9326/9/11/115002

Danish AgriFish Agency (2012), Catch and Landing Statistics, Copenhagen.

Eero, M., J. Hjelm, J. Behrens, K. Buchmann, M. Cardinale, M. Casini, P. Gasyukov, N. Holmgren, J. Horbowy, K. Hüssy, E. Kirkegaard, G. Kornilovs, U. Krumme, F.W. Köster, R. Oeberst, M. Plikshs, K. Radtke, T. Raid, J. Schmidt, M.T. Tomczak, M. Vinther, C. Zimmermann, M. Storr-Paulsen (2015), Eastern Baltic cod in distress: biological changes and challenges for stock assessment, ICES Journal of Marine Science. https://doi.org/10.1093/icesjms/fsv109

European Commission (1991), Council Directive 91/676/EEC concerning the protection of waters against pollution caused by nitrates from agricultural sources, Official Journal of the European Communities, Brussels, Belgium.

European Commission (2000), Directive 2000/60/EC of the European Parliament and of the Council of 23 October 2000 establishing a framework for Community action in the field of water policy, Official Journal of the European Communities, Brussels, Belgium.

European Commission (2008), Directive 2008/56/EC of the European Parliament and of the Council of 17 June 2008 establishing a framework for community action in the field of marine environmental policy (Marine Strategy Framework Directive), Official Journal of the European Union, Brussels, Belgium.

FAO (2014) The State of World Fisheries and Aquaculture 2012, Rome, Food and Agriculture Organisation of the United Nations.

Flaaten, O., K. Heen, K.G. Salvanes. (1995), The invisible resource rent in limited entry and quota managed fisheries - the case of Norwegian purse seine fisheries. Marine Resource Economics 10: 341-356. https://doi.org/10.1086/mre.10.4.42629126

Foley, N., C.W. Armstrong, V. Kahui, E. Mikkelsen, S. Reithe (2012), A review of bioeconomic modelling of habitat-fisheries interactions, International Journal of Ecology 2012, Article ID 861635, 11 pages. 
Foley, N., V. Kahui, C.W. Armstrong, T. van Rensburg (2009), Estimating linkages between redfish and cold water coral on the Norwegian coast, Working Paper No. 0151, Department of Economics, National University of Ireland, Galway.

freshwater aquaculture: Production and profitability gains. Ecological Economics, 75:83-90.

Gordon, H.S. (1954), The economic theory of a common-property resource: The fishery, Journal of Political Economy 62:124-42. https://doi.org/10.1086/257497

Guttormsen, A. G. (2002) Input Factor Substitutability in Salmon Aquaculture. Marine Resource Economics, 17, 91-102. https://doi.org/10.1086/mre.17.2.42629354

Guttormsen, A. G. 2008. Faustman in the Sea, Optimal Harvesting of farmed fish. Marine Resource Economics, 23(4), 401-410. https://doi.org/10.1086/mre.23.4.42629671

Norwegian Institute of Marine Research (2011) Vurdering av eutrofieringssituasjonen i kystområder, med særlig fokus på Hardangerfjorden og Boknafjorden. Rapport fra Ekspertgruppe oppnevnt av Fiskeri- og Kystdepatementet. Havforskningsinstituttet, Bergen.

Helcom (2007), Baltic Sea Action Plan, Helcom Ministerial Meeting, Krakow, Poland, 15 November 2007.

Helcom (2014), Eutrophication status of the Baltic Sea 2007-2011 - A concise thematic assessment, Baltic Sea Environment Proceedings No. 143, Helcom, Baltic Marine Environment Protection Commission, Helsinki, Finland.

ICES (2012), Report from the Advisory Committee of Fisheries Management. ICES Advice, 2012.

ICES (2015), ICES Advice on fishing opportunities, catch and effort, Baltic Sea Ecoregion, version 4, 8.3.2 Cod (Gadus morhua) Western Baltic stock in Subdivisions 22-24 (Western Baltic Sea), 28 August 2015 .

IMR (2011) Vurdering av eutrofieringssituasjonen i kystområder, med særlig fokus på Hardangerfjorden og Boknafjorden. Rapport fra Ekspertgruppe oppnevnt av Fiskeri- og Kystdepatementet. Havforskningsinstituttet, Bergen.

Inefficiency. Journal of Regional Science, 46, 605-625.

Johansson, D., Ruohonen, K., Kiessling, A., Oppedal, F., Stiansen, J.-E., Kelly, M., Juell, J.-E., 2006. Effect of environmental factors on swimming depth preferences of Atlantic salmon (Salmo salar L.) and temporal and spatial variations in oxygen levels in sea cages at a fjord site. Aquaculture 254, 594-605. https://doi.org/10.1016/j.aquaculture.2005.10.029

Johnsen, G. and E. Sakshaug (2000) Monitoring of harmful algal blooms along the Norwegian coast using bio-optical methods. S. Afr. J. Mar. Sci. 22, 309-321.

https://doi.org/10.2989/025776100784125726

KLIF (2010) Vurdering av nye tekniske løysingar for å redusere utsleppa frå fiskeoppdrett i sjø. TA 2749, 2010. IRIS, Stavanger.

Lindebo, E., A. Hoff, N. Vestergaard (2002), Economic and physical measures of capacity: A comparative analysis of Danish trawlers. Paper presented at the $\mathrm{XI}^{\text {th }}$ biannual Conference in the International Institute of Fisheries Economics and Trade, Wellington, New Zealand, august.

McCann K, Yodzis P. (1994), Nonlinear dynamics and population disappearances. American Naturalist 144 (5): 873-9. https://doi.org/10.1086/285714

Nagai, T., (2003), Recovery of fish stocks in the Seto Inland Sea. Marine Pollution Bulletin 47: 126-131. https://doi.org/10.1016/So025-326X(03)00100-0

Neuenfeldt, S., K.H. Andersen, H.-H. Hinrichsen (2009), Some Atlantic cod Gadus morhua in the Baltic Sea visit hypoxic water briefly but often. Journal of Fish Biology 75: 290-294.

https://doi.org/10.1111/j.1095-8649.2009.02281.x 
Nguyen, T.V. (2013), Bioeconomic model of eastern Baltic cod under the influence of nutrient enrichment. Natural Resource Modeling 26 (2), May 2013.

Nguyen, T.V., L. Ravn-Jonsen, N. Vestergaard (2015), Marginal damage cost of nutrient enrichment: The case of the Baltic Sea, Environmental Resource Economics, https://doi.org/10.1007/s10640014-9859-8

Nielsen, R. (2011). Green and technical efficient growth in Danish fresh water aquaciulture.

Nielsen, R. (2012), Introducing individual transferable quotas on nitrogen in Danish fresh water aquaculture: production and profitability, Ecological Economics, 75:83-90.

https://doi.org/10.1016/j.ecolecon.2012.01.002

Nilsen, O. B. (2010) Learning-by-doing or technological leapfrogging: production frontiers and efficiency measurement in Norwegian salmon aquaculture. Aquaculture Economics and Management, 14, 97-119. https://doi.org/10.1080/13657301003776649

Nixon, S.W., B.A. Buckley, (2002), A strikingly rich zone-nutrient enrichment and secondary production in coastal marine ecosystems, Estuaries 25: 782-796.

https://doi.org/10.1007/BF02804905

Oczkowski, A. and S. Nixon (2008), Nutrient over-enrichment and the rise and fall of a coastal fishery; a review of data from the Nile Delta, Egypt. Estuarine, Coastal and Shelf Science 77: 309-319. https://doi.org/10.1016/j.ecss.2007.11.028

Oppedal, F., Dempster, T., Stien, L., 2011. Environmental drivers of Atlantic salmon behaviour in sea-cages: a review. Aquaculture 311, 1-18. https://doi.org/10.1016/j.aquaculture.2010.11.020

Pedersen, S.E, J. Windolf, M. Sørensen, N. Rask, O.T. Jørgensen, P. Wiberg-Larsen (2006), Regional Implementation of the EU Water Framework Directive in the Baltic Sea Catchment, Bernet Catch Executive Summary, Odense, Denmark, February 2006., available at http://naturstyrelsen.dk /media/nst/736968o/1_gb_BC_Exec3omarts_webSmallestsize_HEL.pdf

Pike, A. W., \& Wadsworth, S. L. (1999). Sealice on salmonids: Their biology and control. Advances in Parasitology, Vol 44, 44, 233-337. https://doi.org/10.1016/s0065-308x(08)60233-x

Roll, K.H. (2013) Measuring performance, development and growth when restricting flexibility. Journal of Productivity Analysis. 39(1), 15-25. https://doi.org/10.1007/s11123-012-0265-3

Sandvold, H. N., and R. Tveterås (2014). Innovation and productivity growth in Norwegian production of juvenile salmonids. Aquaculture Economics \& Management 18(2): 149-168.

https://doi.org/10.1080/13657305.2014.903313

Schaefer, M.B. (1957), Some Considerations of Population Dynamics and Economics in Relation to the Management of the Commercial Marine Fisheries, Journal of the Fisheries Research Board of Canada 14:669-81. https://doi.org/10.1139/f57-025

Simmonit, S. and C. Perrings (2005), Indirect economic indicators in bio-economic fishery models: agricultural price indicators and fish stocks in Lake Victoria, ICES Journal of Marine Science, 62: 483-492. https://doi.org/10.1016/j.icesjms.2005.01.012

Smith, M.D, F. Asche, L.S. Bennear, A. Oglend (2014), Spatial-dynamics of hypoxia and fisheries: The case of Gulf of Mexico brown shrimp, Marine Resource Economics, volume 29:2:111-131.

Stern, N. (2006), The Economics of Climate Change: The Stern Review. Cambridge University Press. Cambridge. https://doi.org/10.1086/676826

Swedish Central Bank (2015), Räntor och valutakurser, Sök räntor och valutakurser: http://www.riksbank.se/sv/Rantor-och-valutakurser/Sok-rantor-och-valutakurser/ (retrieved 2015-10-01). 
Swedish Environmental Protection Agency (2013), Yearly follow-up on environmental objectives, Report 6557:2013.

Tallqvist, M., E. Sandberg-Kilpi, E. Bonsdorff (1999), Juvenile flounder, Platichthys flesus (L.), under hypoxia: effects on tolerance, ventilation rate and predation efficiency. J. Exp. Mar. Biol. Ecol. 242: 75-93. https://doi.org/10.1016/s0022-0981(99)ooog6-9

Torissen, O., S. Jones, A. Guttormsen, F. Asche, T. E. Horsberg, Ove Skilbrei, D. Jackson, and F. Nilsen (2013) Salmon Lice - Impact on Wild Salmonids and Salmon Aquaculture, Journal of Fish Diseases. 36, 171-194. https://doi.org/10.1111/jfd.12061

Torrissen, O., R. E. Olsen, R. Toresen, G. I. Hemre, A. G. J. Tacon, F. Asche, R. W. Hardy, S. P. Lall. 2011. "Atlantic Salmon (Salmo salar) - The Super-Chicken of the Sea?" Reviews in Fisheries Science, 19, 3, 257-278. https://doi.org/10.1080/10641262.2011.597890

Tveterås, R. and G.M. Batteese (2006) Agglomeration externalities, productivity and technical

Tveterås, S. (2002), Norwegian salmon aquaculture and sustainability: the relationship between environmental quality and industry growth, Marine Resource Economics 17(2):121-132. https://doi.org/10.1086/mre.17.2.42629356

Udumyan, D.S, D. Ami, P. Cartigny (2010), Integrating habitat concerns into Gordon-Schaefer model, Document de Travail no 2010-32, GREQAM (Groupement de Recherche en Economie Quantitative D'Aix-Marseille).

Vallin, L. and A. Nissling (2000), Maternal effects on egg size and egg buoyancy of Baltic cod, Gadus morhua. Implications for stock structure effects on recruitment. Fish. Res., 49: 21-37. https://doi.org/10.1016/S0165-7836(00)00194-6

Vassdal, T. \& H.M.S. Holst (2011) Technical progress and regress in Norwegian salmon farming: a Malmquist index approach. Marine Resource Economics, 26, 329-342.

https://doi.org/10.5950/0738-1360-26.4.329 



\title{
Dansk resume
}

\author{
Introduktion
}

Denne rapport bidrager til forståelsen af hvordan det samfundsøkonomiske bidrag fra nordiske fiskeri og akvakultur påvirkes af miljø og miljøforvaltning, med fokus på næringsstoffer og kvælstof. Rapporten indeholder to case studier af hvordan samfunds$ø$ øonomiske bidrag fra dansk og svensk fiskeri efter torsk i den vestlige del af Østersøen påvirkes af koncentrationen af kvælstof i havet, samt hvordan vækstraterne for laks $\mathrm{i}$ havbrug i Boknafjorden påvirkes af kvælstofkoncentrationen. Endvidere blev der i juni 2015 afholdt en nordisk workshop med titlen Fiskeri, akvakultur og havmiljø: miljømæssige udfordringer og regulering, med fokus på kvælstof. På denne blev resultaterne fremlagt, såvel som der yderligere var en række præsentationer om betydningen af næringsstoffer, og forvaltningen heraf, for nordisk fiskeri og akvakultur. Diskussionen på workshoppen er opsummeret i denne rapport.

\section{Case studie I: Forvaltning af fiskeri under påvirkning af næringsstoffer - Torskefiskeri i den vestlige del af Østersøen}

Formålet med dette studie var at analysere det samfundsøkonomiske bidrag fra den danske og svenske fiskeflåde af at reducere kvælstofkoncentrationen og ændre fiskeripolitikken i den vestlige del af Østersøen. Analysen tog udgangspunkt $i$, at man tidligere har vist at sammenhængen mellem koncentrationen af kvælstof og størrelsen af torskebestanden var positiv i perioden fra 1940-1980. I denne periode havde tilførslen af næringsstoffer en positiv effekt på størrelsen af torskebestanden. Siden 1980'erne er kvælstof fra et miljømæssigt synspunkt imidlertid blevet betragtet som problematisk. Samtidig er der i miljøpolitikken blevet indført begrænsninger på udledning af kvælstof og næringsstoffer i de fleste lande omkring Østersøen. De senere år har der været et fald i udledningen af kvælstof og fosfor til Østersøen, hvorimod den målte koncentrationen af næringsstoffer i vandet ikke er reduceret tilsvarende. Algebiomassen har ikke været faldende og udbredelsen af havbundsområder med iltsvind er stigende. I analysen er anvendt en bio-økonomisk model af fiskeriet, hvor den samfundsøkonomiske optimale flådestørrelse for torskefiskeriet med passive redskaber i Den vestlige del af 
Østersøen identificeres. Denne model er udvidet således at effekten fra kvælstofkoncentrationen indgår, dvs. modellen identificerer en kombineret optimal flådestørrelse og kvælstofkoncentration der tilsammen leder til samfundsøkonomisk optimum for fiskeriet. Den grundlæggende sammenhæng inkluderet i modellen er at stigende kvælstofkoncentrationen alt andet lige medfører større torskebestande indtil et vist punkt. Efter dette punkt medfører højere kvælstofkoncentration lavere torskebestand, på grund af eutrofiering. På trods af at den nuværende kvælstofkoncentration i Vestøstersøen er højere end det optimale, vurderes det at den observerede koncentration ikke er langt fra den optimale koncentration. Resultaterne indikerede at effekten af ændrede kvælstofkoncentrationer på det samfundsøkonomiske bidrag fra fiskeriet i den vestlige del af Østersøen er lille. Derimod er der store samfundsøkonomiske gevinster af at reducere flådens størrelse. Det samfundsøkonomiske bidrag fra torskefiskeriet i den vestlige del af Østersøen kan således forbedres betydeligt ved en flådereduktion, men kvælstof vurderes ikke at have stor betydning herfor.

\section{Case studie II: Næringsstoffers påvirkning af vækstraten for laks i havbrug i Bokna Fjorden i Norge}

Formålet med dette studie var at estimere samspillet mellem koncentrationen af næringsstoffer i havet og vækstraten for laks på havbrug i Bokna Fjorden og dermed afdække hvordan havbrugene påvirkes af forurening med næringsstoffer, uanset om de stammer fra landbaserede kilder eller fra andre havbrug. Der blev gennemført detaljerede undersøgelser og regressionsanalyser, men det var ikke muligt at identificere en sammenhæng mellem næringsstofkoncentrationen og væksten af laks. Årsagen forbliver spekulation, men vurderes at være at mindre end $3 \%$ af næringsstofbelastningen i Norge er forårsaget af menneskelig aktivitet, i modsætning til Danmark hvor det er 82 \%. På trods af at det er en politisk målsætning at reducere udledningen af næringsstoffer i Norge, er konklusionen, at høj koncentration af næringsstoffer ikke udgør noget betydeligt problem for akvakultur. I varme somre kan der dog opstå iltsvind lokalt. 


\section{Workshop: Perspektiver om betydningen af kvælstof for nordisk fiskeri og akvakultur}

Workshoppen Fiskeri, akvakultur og havmiljø: miljømæssige udfordringer og regulering, med fokus på kvælstof blev afholdt i København i juni 2015. Der fokuseredes på næringsstoffers betydning for samfundsøkonomi og bæredygtig vækst i nordisk fiskeri og akvakultur. Forskellige tilgange til forvaltning af havmiljøet blev diskuteret, herunder økosystem forvaltning, forvaltning baseret på naturkapital og økonomisk værdisætning af økosystemtjenester. De potentielle problemer, som kræver forvaltning for at blive håndteret hensigtsmæssigt fra et samfundsøkonomisk perspektiv, der blev drøftet var: 1) udledning af kvælstof og fosfor fra akvakultur som fremkalder negative miljøpåvirkninger på vandmiljø og andre fiskeopdræt, 2) kvælstof og fosfor optag i opdrættede muslinger og tang som via renseeffekten har positiv miljøeffekt, 3) effekt af næringsstofkoncentration i marine områder på fiskebestandenes produktivitet og fiskeriets økonomi, som er positive ved lave koncentrationer som følge af forøget fødegrundlag for fiskene, men negative ved høje koncentrationer på grund af eutrofiering, og 4) fjernelse af kvælstof og fosfor i vildtfangede fisk, som fremkalder en positiv miljøeffekt. Diskussionen viste at på trods af at fiskeriet påvirkes af høje koncentrationer af næringsstoffer, forventes en evt. reduktion af næringsstoffer ikke at forårsage en større effekt på det samfundsøkonomiske bidrag fra torskefiskeriet. Derfor kan det samfunds$ø$ øonomiske bidrag fra fiskeriet i langt højere grad forbedres via anvendelse af fiskeriforvaltningsinstrumenter som individuelt omsættelige kvoter for at "undgå at der er for mange fiskere til at fange for få fisk". For akvakultur synes kvælstof ikke at udgøre nogen større udfordring for økosystemerne i Norge. Situationen er dog helt anderledes i Østersøen. Her er det den væsentligste barriere for bæredygtig vækst i akvakultur på grund af den nuværende miljøforvaltning af næringsstoffer. Mulighederne for bæredygtig vækst akvakultur i Østersøområdet blev diskuteret og følgende muligheder blev nævnt: 1) mere effektiv kvælstofforvaltning i form af individuelt omsættelige kvælstofkvoter, 2) rensning af vand ved fjernelse af næringsstoffer gennem fiskeri, 3) rensning af vand ved fjernelse af næringsstoffer gennem muslinge- og tangopdræt (herunder kompensationsopdræt), og 4) videreudvikling af miljøvenlige teknologier til havbrug samt lukkede/delvist lukkede (recirkulerede) systemer, hvor fiskeproduktion er afkoblet fra miljøet. 


\section{Konklusion}

Rapporten bidrager til at identificere betydningen af kvælstof for det samfundsøkonomiske bidrag fra nordisk fiskeri og akvakultur. Det findes at kvælstof har betydning i Østersøen, men at der ikke er indikationer af væsentlige problemer andre steder i Norden. Samspillet mellem fiskeri og akvakultur på den ene side, og kvælstof på den anden, er således primært af interesse i Danmark, Finland og Sverige. I Finland er fosfor dog vigtigere end kvælstof. Kvælstofforvaltning har væsentlig betydning for akvakultur i Østersøen og vurderes at være en begrænsende faktor for bæredygtig vækst. Skal der opnås bæredygtig vækst i dansk, finsk og svensk akvakultur, skal forvaltningen af kvælstof nødvendigvis håndteres. Fiskeri og akvakultur har mulighed for at videreudvikle renseforanstaltninger i form af fjernelse af næringsstoffer via fangst af fisk, samt ved at opdrætte muslinger og tang. Muslinge- og tangproduktion eksisterer allerede i dag flere steder i Norden og videreudvikling kan være af fælles nordisk interesse. Renseforanstaltninger har positiv miljøeffekt, hvorfor udvikling heraf kan overvejes inddraget i miljøpolitikken. Fx ved at indføre en betalingsordning hvor landmænd betaler muslingeopdrættere og fiskere for at rense efter sig. Rapporten har ikke vurderet økonomien heri.

Baseret på de to casestudier og input fra workshoppen, vurderes følgende konklusioner at være af aktuel relevans:

- Der er ingen indikation af at det samfundsøkonomiske bidrag fra dansk og svensk torskefiskeri i den vestlige del af Østersøen vil blive påvirket betydeligt af ændringer i kvælstofkoncentrationen.

- Der er ingen indikation af at profitabiliteten af norsk havbrug vil blive mærkbart påvirket af ændringer i næringsstofkoncentrationen.

- Fiskeriet i den vestlige del af Østersøens bidrag til samfundsøkonomien forventes forbedret når strukturtilpasningen efter individuelt omsættelige kvoter gradvist fortsætter i Danmark og hvis de introduceres i svensk demersalt fiskeri.

- Kvælstofforvaltningen er den helt afgørende barriere for bæredygtig vækst i akvakultur i Østersøen.

Næringsstoffer og kvælstof er af stor betydning for akvakultur i Østersøen, der er indikationer af at betydningen er beskeden for torskefiskeriet i den vestlige del af Østersøen og at betydningen for fiskeri og akvakultur i resten af Norden er yderst beskeden. 


\section{Appendix A. Description of the bio-economic model of fisheries applied in case I}

In this appendix, the fisheries management model introduced in chapter 2.4 is formally operationalized to handle the influence of nutrients on the fish stock and catches. The model is based on the classical Gordon-Schaefer bio-economic model (Gordon 1954; Schaefer 1957), but with an added harvesting function that is depending not only on effort, but also on the nitrogen level.

The total revenue (TR) in the current period (period o) for the fishery is given by:

$$
\mathrm{TR}_{0}=\mathrm{p} * \mathrm{~h}_{0}+\mathrm{OT}
$$

where $p$ is the unit price of cod, $h$ is harvest of cod, and OT is revenues from other species. $p$ is a fixed price, an assumption motivated by the fishery in question being small and thus facing an exogenous price. $h$ is explained below, while other revenues, including from other species or stocks, are assumed to follow the same development as revenues from the cod fishery.

The total cost in the current fishery $\left(\mathrm{TC}_{0}\right)$ is defined as total cost with labor and capital in alternative use. All costs are considered to be variable, since the model is used for comparing situations in the long run. Combining revenues and costs in the current situation, the welfare contribution $\left(\mathrm{W}_{\mathrm{o}}\right)$, consisting of resource rent and producer surplus, is identified as:

$$
\mathrm{W}_{0}=\mathrm{p} * \mathrm{~h}_{0}+\mathrm{OT}-\mathrm{TC}_{0}
$$

The current situation forms the basis for the calculation of future revenues and costs. Assuming constant factor prices, total costs in a future period $\left(\mathrm{TC}_{1}\right)$ are determined by the current costs and the relative change in effort level such that:

$$
\mathrm{TC}_{1}=\mathrm{TC}_{0}\left(\frac{\mathrm{E}_{1}}{\mathrm{E}_{0}}\right)(1+\mathrm{v})
$$


where $v$ is a parameter for the difference in fishing efficiency brought about by the use of input factors. When $v>0$, some fishermen have a higher level of skill than others, causing an infra-marginal rent (Copes, 1972), implying that the cost function is convex. Here we assume $v=0.33 .{ }^{7}$

The harvest is assumed to be a function of biomass $(X)$ and effort such that:

$$
h=\mathrm{f}(\mathrm{X}(\mathrm{E}, \mathrm{N}))
$$

where $\mathrm{N}$ is nitrogen. It is assumed that capacity utilization of the average vessel is unchanged and measured by the number of days at sea per vessel per year. Moreover, it is assumed that relative effort levels of each fleet segment applied to each of the stocks remain constant. Finally, since the cod stock in the Western part of the Baltic Sea is shared among countries and is subject to widespread quota regulations, it is assumed that each national fleet catches a constant share of the total catch. Hence, catches of non-included vessels develop exactly as catches of included vessels. The relationship between biomass and effort measured in two time periods $o$ and 1 for a specific fleet and a fixed nitrogen level is:

$$
\frac{\mathrm{X}_{1}}{\mathrm{X}_{0}}=\frac{\mathrm{E}_{0}}{\mathrm{E}_{1}}
$$

In steady-state, harvest equals growth of the stock. Without taking nitrogen into account, the growth is:

$$
G(X)=g\left(1-\frac{X}{K_{M A X}}\right) X
$$

where $\mathrm{G}(\mathrm{X})$ is the growth of the stock, $\mathrm{g}$ is the intrinsic growth rate, and $\mathrm{K}_{\mathrm{MAX}}$ is the carrying capacity of the eco-system, i.e., the maximum stock size possible. Assuming that the intrinsic growth rate and the carrying capacity are affected by nitrogen concentrations, as illustrated in Figure $1 \mathrm{~b}$, we adjust the growth function by assuming that the intrinsic growth rate $(\mathrm{g})$ is:

$$
\mathrm{g}(\mathrm{N})=\mathrm{w} \cdot \mathrm{K}_{M A X}(N)
$$

\footnotetext{
TThe estimate $v=0.33$ is based on a survey of actual differences in performance in fishing for cod in the North Sea (Lindebo, Hoff, and Vestergaard, 2002). Vessel performance is measured by a score based on Data Envelopment Analysis (DEA); the latter indicates how many inputs a given vessel uses when most effective.
} 
and the carrying capacity $\left(\mathrm{K}_{\mathrm{MAX}}\right)$ is given by:

$$
\mathrm{K}_{\mathrm{MAX}}(\mathrm{N})=\mathrm{A}+\beta \mathrm{N}-\gamma \mathrm{N}^{2}
$$

where $\mathrm{N}$ is the nitrogen concentration in the sea, $\mathrm{A}$ is the carrying capacity at very low levels of nitrogen and $\beta$ and $\gamma$ are parameters indicating the rate at which the nitrogen level is affecting the maximum stock. Thus in the present case it is assumed that the growth rate is connected to the maximum obtainable stock, given the nitrogen level. Assuming in this way that the intrinsic growth rate is a proportion of carrying capacity simplifies the calculations. The rationale behind this is the understanding that the growth rate depends on carrying capacity. We further assume that the intrinsic growth rate is proportional to the carrying capacity by a factor $\mathrm{w}$, and thus that there is constant return to scale for the intrinsic growth of the fish stock.

Using the adaptations described above, we get the following logistic growth function:

$$
G(X, N)=w\left(A+\beta N-\gamma N^{2}\right)\left(1-\frac{X}{\left(A+\beta N-\gamma N^{2}\right)}\right) X
$$

Assuming that the harvest function is $\mathrm{h}=\mathrm{eEX}$, where e is the catchability coefficient, we can solve for steady-state $(h=G(X, N))$ stock levels:

$$
\mathrm{eEX}=w\left(A+\beta N-\gamma \mathrm{N}^{2}\right)\left(1-\frac{\mathrm{X}}{\left(\mathrm{A}+\beta \mathrm{N}-\gamma \mathrm{N}^{2}\right)}\right) \mathrm{X}
$$

Giving:

$$
X=A+\beta N-\gamma N^{2}-\frac{e E}{w}
$$

Substituting this function into the harvest function, we get:

$$
\begin{aligned}
& h=e E\left(A+\beta N-\gamma N^{2}-\frac{e E}{w}\right) \\
& h=e E A+e E \beta N-e E \gamma N^{2}-\frac{e^{2} E^{2}}{w}
\end{aligned}
$$

Assuming initial steady state, the parameters of the yield function can be calibrated based on available data for harvests, effort, and nitrogen levels in the start year. With $\mathrm{eA}=\mathrm{a}, \mathrm{e} \beta=\mathrm{c}, \mathrm{e} \gamma=\mathrm{d}$, and $\frac{\mathrm{e}^{2}}{\mathrm{w}}=\mathrm{b}$, we can express (13) as: 


$$
\mathrm{h}=\mathrm{aE}-\mathrm{bE}^{2}+\mathrm{cEN}-\mathrm{dEN}^{2}
$$

This function captures the biological relationships shown in Figure 1.

Inserting the cost (3) and harvest (14) functions into the welfare function (2), we have:

$$
\mathrm{W}^{1}=\mathrm{p} *\left(a \mathrm{E}_{1}-\mathrm{bE}_{1}^{2}+\mathrm{cE}_{1} \mathrm{~N}_{1}-\mathrm{dE}_{1} \mathrm{~N}_{1}^{2}\right)+\mathrm{OT}-\mathrm{TC}_{0}\left(\frac{\mathrm{E}_{1}}{\mathrm{E}_{0}}\right)^{(1+\mathrm{v})}
$$

which is maximized under three scenarios:

$$
\begin{aligned}
& ; N=N_{0} \\
& ; E=E_{0}
\end{aligned}
$$

In scenario 1 (equation 16), the welfare contribution is maximized with respect to effort under unchanged nitrogen concentration, whereas welfare is maximized with respect to nitrogen concentration in scenario 2 (equation 17), given unchanged effort. In scenario 3 (equation 18), welfare is maximized varying both effort and nitrogen concentration.

Because there is no single analytical solution for the above problem, a numerical solution is required. Since the empirical calculations are based on financial results, the resource rent and producer surplus in the harvest sector cannot be separated, meaning that the welfare contribution of fisheries refers to the sum of the two. The operational model presented was developed using an Excel spreadsheet, with maximizations obtained using the Solver facility. 


\section{Appendix B. Description of the estimation model of aquaculture applied in case II}

In this appendix, the theoretical foundation of the estimation model introduced in chapter 3.4 is described. The model is based on the classical Faustmann model (Faustmann 1849) of optimal rotation time for a single year-class extended with the nitrogen level.

A farmer will stock a single year-class of juvenile fish at some initial time and batch harvest the residual stock $T$ months later (Bjørndal, 1988). ${ }^{8}$ In what follows, we consider the harvest time $T$ to be strictly exogenous in order to focus our attention on the potential economic impacts of hypoxia over typical production cycles of fixed duration. Given that the largest portion of variable costs during grow out is due to the feeding of fish, our subsequent analysis focuses on feeding as the primary variable cost of production (Guttormsen, 2002). Importantly, the biological literature informs us that fish growth, and therefore biomass growth is a function not only of time (i.e., fish age), but also of things such as water temperature, photoperiod, fish size, stocking density, and the prevalence of parasites and disease (Pike and Wadsworth, 1999). Fish are also likely to experience a reduction in their appetite due to low dissolved oxygen levels, which will affect the quantity of feed use. To incorporate these potential impacts into a farmer's discounted net revenues from a single production cycle, we allow for farm biomass growth $\dot{B}$ to be a function of a time varying level of nitrogen loadings, $L_{t}$. In other words, $L_{t}$ is an exogenous scenario of nitrogen per-fish over a single production cycle. If we further incorporate a farmer's ability to employ costly chemical delousing treatments to their fish stock, the farmer's discounted profits, similar to a single rotation Faustmann model, are

$$
\Pi(T)=P \cdot\left(B_{0}+\int_{0}^{T} \dot{B}\left(t, L_{t}\right) \cdot d s\right) \cdot e^{-r T}-C_{f} \int_{0}^{T} F C R \cdot \dot{B}\left(t, L_{t}\right) \cdot e^{-r t} \cdot d s
$$

\footnotetext{
${ }^{8}$ Alternatively, as is observed in our data, some farms will release and harvest their fish over multiple months.
} 
Where $T$ is harvest time, $P$ is the per $\mathrm{kg}$ price of fish, $B_{0}$ is the initial nitrogen-free stock of biomass and $\dot{B}(\cdot)$ is fish biomass growth. Further, $C_{f}$ is the unit price of feed, $F C R$ is the feed conversion rate (i.e., the quantity of feed use per period per $\mathrm{kg}$ of biomass growth), $r$ is the farmer's discount rate, $N$ is the total number of treatments and $T_{n}$ is the time at which treatment $n \in[1, N]$ occurs. In this form we have assumed that the $\mathrm{kg}$ price of fish and the feed conversion rate are both independent of the nitrogen loading In other words, 9 the price of fish does not depend on product size, quality (or marketability) and/or industry reputation - thereby not depending on the degree to which nitrogen impact these (Asche and Guttormsen, 2001).

By incorporating nitrogen loadings in this fashion we may use Equation 1 to devise the economic impact of a particular nitrogen loading scenario (as defined by $L_{t}$ and the associated treatment schedule) on growth rates and thereby on discounted farm profits over a single production cycle of fixed duration.

To estimate the impact of nitrogen on the biological growth rate of farm biomass we express $r_{i t}$ as a non-linear function of a vector of time dependent explanatory variables, including the level of nitrogen per-fish. Specifically, we let $\ln \left(1+r_{i t}\right)=x_{i t}^{\prime} \beta$, where $x_{i t}^{\prime}$ is a vector of explanatory variables and $\beta$ is the associated vector of parameters to be estimated. Allowing for the presence of additive time-invariant farm-specific effects $\alpha_{i}$, month-specific effects $\gamma_{i t}$ (which capture seasonality), and an unobservable idiosyncratic error component $\epsilon_{i t}$, our model for farm $i$ at time $t$ is. ${ }^{10,11}$

$$
\ln \left(\frac{\text { Biomass }_{i t}}{\text { Biomass }_{i t-1}}\right)=x_{i t}^{\prime} \beta+\alpha_{i}+\gamma_{i t}+\epsilon_{i t}
$$

Because fish growth is likely to be a lagged production process with time lag, whereby the impacts of certain explanatory variables are distributed over time, we allow for $x_{i t}^{\prime}$ to include lagged values of certain explanatory variables. In this form, our model is a finite distributed lag linear panel model. In this report, we estimate a linearized form of our model using the monthly farm-level data from all salmon producing farms in Rogaland between May 2010 and Dec 2013.

\footnotetext{
${ }_{9}^{9}$ Assuming a fixed feed conversion rate effectively assumes that the elasticity of fish growth with respect to nitrogen is exactly equal to the elasticity of feed use with respect to nitrogen. In other words, a $1 \%$ increase in nitrogen will result in a $1 \%$ decrease in both feed use and fish growth.

${ }^{10}$ Equation 2 assumes that all ancillary changes in biomass occur at the end of each month. Further analysis, assuming that all or some portion of the changes instead occur at the beginning of each month, confirms that such an assumption has little to no effect on model results.

${ }^{11}$ This setup explicitly disallows for the possibility of lice-induced mortality by directly accounting for the level of reported mortalities in $A B_{i t}$. For comparison, when we remove mortalities from $A B_{i t}$ (i.e., allowing for the possibility of lice-induced mortality) we discover no qualitative changes to our results.
} 


\section{Appendix C. Workshop program}

Title: $\quad$ Fisheries, aquaculture and the marine environment: Environmental challenges and regulation, with focus on nitrogen.

Place: $\quad$ Radisson Blu Falconer Hotel \& Conference Center, Copenhagen, Denmark.

Time: $\quad$ 15-16 June 2015 .

\section{Program}

AG Fish Workshop

Monday 15 June

Fisheries and aquaculture in the marine environment

10:00

10:15

11:00

$11: 45$
Presentation/Welcome/Introduction

Max Nielsen, University of Copenhagen

1. Economics of the ecosystem approach to management: Forest experiences

Jette Bredahl Jacobsen, University of Copenhagen

2. Aquaculture in the Baltic region: A prerequisite for circular production systems

Anders Kiesling, Swedish University of Agricultural Sciences, Uppsala

3. Compensation farming of mussels together with marine farming of trout in Horsens Fiord

Teis Boderskov, Hjarnø Havbrug 


$\begin{array}{ll}\text { 12:30 } & \text { Lunch } \\ \text { 13:30 } & \text { 4. Status and regulation of the marine environment in the Baltic Sea } \\ \text { Jacob Hagberg, Swedish Ministry of the Environment } \\ \text { 14:15 } \\ \text { 5. Economic inefficiency and environmental impact: An application to } \\ \text { aquaculture production } \\ \text { Kristin Roll, University of Stavanger } \\ \text { Coffee break } \\ \text { 15:00 } \\ \text { 6. Bio-economic model of Eastern Baltic cod under the influence of nu- } \\ \text { trient enrichment } \\ \text { Lars Ravn Joensen, University of Southern Denmark } \\ \text { 19:00 } \\ \text { 7. Management and economics of cod fisheries in the West Baltic Sea } \\ \text { and nitrogen discharges } \\ \text { Cecilia Hammarlund, AgriFood Economics Centre, Sweden and Max Niel- } \\ \text { sen, University of Copenhagen } \\ \text { End of day one } \\ \end{array}$

Tuesday 16 June

Fisheries and aquaculture in the marine environment

9:00 8. The Value of Environmental Impact of Fisheries on Nutrient dynamics

Jarno Virtanen, Natural Resources Institute Finland

9:30 9. Importance of nitrogen for aquaculture growth in Denmark Rasmus Nielsen, University of Copenhagen

10:00 10. Marine fish farming and nitrogen in Finland

Jari Setälä, Natural Resources Institute Finland 
$10: 30$

11:00

11:30

12:00

\section{Coffee break}

11. Externalities, nitrogen discharges and marine aquaculture: a focus on the Bokna Fiord

Frank Asche, University of Stavanger

12. Put a value on nitrogen, and let enterprises compete for it: How do we transform public management for that?

Mogens Schou, Aquamind A/S

Lunch and end of workshop 



\section{Appendix D. Workshop participant list}

\begin{tabular}{|c|c|c|c|}
\hline Participant & Institution & Country & e-mail \\
\hline 1. Anders Kiesling & $\begin{array}{l}\text { Swedish University of } \\
\text { Agricultural Sciences, Uppsala }\end{array}$ & Sweden & Anders.Kiessling@slu.se \\
\hline 2. Cecilia Hammarlund & $\begin{array}{l}\text { AgriFood Economics Centre and } \\
\text { Lund University, Department of } \\
\text { Economics }\end{array}$ & Sweden & Cecilia.Hammarlund@agrifood.lu.se \\
\hline 3. Staffan Waldo & $\begin{array}{l}\text { AgriFood Economics Centre and } \\
\text { Lund University, Department of } \\
\text { Economics }\end{array}$ & Sweden & Staffan.Waldo@slu.se \\
\hline 4. Jacob Hagberg & $\begin{array}{l}\text { Swedish Ministry of the } \\
\text { Environment }\end{array}$ & Sweden & Jacob.hagberg@regeringskansliet.se \\
\hline 5. Frank Asche & University of Stavanger & Norway & frank.asche@uis.no \\
\hline 6. Kristin Roll & University of Stavanger & Norway & kristin.h.roll@uis.no \\
\hline 7. Jarno Virtanen & $\begin{array}{l}\text { Natural Resources Institute } \\
\text { Finland }\end{array}$ & Finland & Jarno.Virtanen@luke.fi \\
\hline 8. Jari Setala & $\begin{array}{l}\text { Natural Resources Institute } \\
\text { Finland }\end{array}$ & Finland & Jari.Setala@luke.fi \\
\hline 9. Sally Clink & Baltic Regional Advisory Council & International & sc@bsac.dk \\
\hline 10. Marie Maar & $\begin{array}{l}\text { University of Aarhus, Depart- } \\
\text { ment of Bioscience }\end{array}$ & Denmark & mam@bios.au.dk \\
\hline 11. Christian Mohn & $\begin{array}{l}\text { University of Aarhus, Depart- } \\
\text { ment of Bioscience }\end{array}$ & Denmark & chmo@bios.au.dk \\
\hline 12. Brian Thomsen & Danish Aquaculture & Denmark & brian@danskakvakultur.dk \\
\hline 13. Teis Boderskov & Hjarnø Havbrug A/S & Denmark & teis@havbrug.dk \\
\hline 14. Torben Wallach & Musholm A/S & Denmark & tv@musholm.com \\
\hline 15. Flemming Møhlenberg & $\mathrm{DHI}$ & Denmark & flm@dhigroup.com \\
\hline 16. Lars Ravn-Jonsen & $\begin{array}{l}\text { University of Southern } \\
\text { Denmark, Esbjerg }\end{array}$ & Denmark & Irj@sam.sdu.dk \\
\hline
\end{tabular}




\begin{tabular}{|c|c|c|c|}
\hline Participant & Institution & Country & e-mail \\
\hline 17. Mikkel Stage & $\begin{array}{l}\text { Danish Ministry of Food, } \\
\text { Agriculture and Fisheries, the } \\
\text { AgriFish Agency }\end{array}$ & Denmark & miksta@naturerhverv.dk \\
\hline 18. Janne Palomino Dalby & $\begin{array}{l}\text { Danish Ministry of Food, } \\
\text { Agriculture and Fisheries, the } \\
\text { AgriFish Agency }\end{array}$ & Denmark & jpda@naturerhverv.dk \\
\hline 19. Lars Ole Hansen & $\begin{array}{l}\text { Danish Ministry of Food, } \\
\text { Agriculture and Fisheries }\end{array}$ & Denmark & loha@fvm.dk \\
\hline 20. Jakob Jensen & $\begin{array}{l}\text { Danish Ministry of Food, } \\
\text { Agriculture and Fisheries }\end{array}$ & Denmark & jakjen@fvm.dk \\
\hline 21. Kristine Dose Bertelsen & $\begin{array}{l}\text { Danish Ministry of Food, } \\
\text { Agriculture and Fisheries }\end{array}$ & Denmark & kdbe@fvm.dk \\
\hline 22. Thomas Bjerre Larsen & $\begin{array}{l}\text { Danish Ministry of the Environ- } \\
\text { ment, the Environmental } \\
\text { Protection Agency }\end{array}$ & Denmark & thobj@mst.dk \\
\hline 23. Mogens Schou & Aquamind $\mathrm{A} / \mathrm{S}$ & Denmark & Mogens.schou@aquamind.dk \\
\hline 24. Jette Bredahl Jacobsen & University of Copenhagen, IFRO & Denmark & jbj@ifro.ku.dk \\
\hline 25. Ayoe Hoff & University of Copenhagen, IFRO & Denmark & ah@ifro.ku.dk \\
\hline 26. Rasmus Nielsen & University of Copenhagen, IFRO & Denmark & rn@ifro.ku.dk \\
\hline 27. Frank Jensen & University of Copenhagen, IFRO & Denmark & fje@ifro.ku.dk \\
\hline 28. Tenaw Gedefaw Abate & University of Copenhagen, IFRO & Denmark & tga@ifro.ku.dk \\
\hline 29. Max Nielsen & University of Copenhagen, IFRO & Denmark & max@ifro.ku.dk \\
\hline
\end{tabular}


Nordic Council of Ministers

Ved Stranden 18

DK-1061 Copenhagen K

www.norden.org

\section{Nordic fisheries and aquaculture}

This report contributes to the understanding of how the the socioeconomic contribution of Nordic fisheries/aquaculture are affected by the environment and environmental management, with focus on nitrogen. The report contains two case studies of how the socio-economic contribution of Danish/Swedish cod fishery in the Western Baltic Sea are affected by the nitrogen in the sea, and on how salmon growth rates in aquaculture in the Bokna Fiord are affected by nitrogen concentration. A Nordic workshop was held with the title: Fisheries, aquaculture and the marine environment: Environmental challenges and regulation, with focus on nitrogen. The finding of the case studies was presented at the workshop, together with presentations made by invited speakers on the role of nutrients and their management for Nordic fisheries/aquaculture. The discussion at the workshop is summarized in this report.

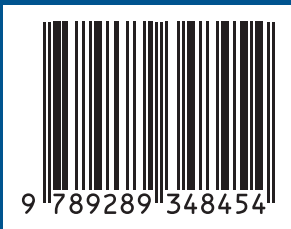

